\title{
THE GEOGRAPHIC DISTRIBUTION OF PRODUCTION ACTIVITY IN THE UK
}

\author{
Michael P. D evereux \\ University of Warwick and Institute for Fiscal Studies \\ Rachel G riffith \\ Institute for Fiscal Studies \\ Helen Simpson \\ Institute for Fiscal Studies
}

September 1999

\begin{abstract}
There has much recent academic and policy interest in the issue of spatial clustering of economic activity, with most attention paid to the geographic concentration of high-tech industries. This paper describes patterns of geographic and industrial concentration in UK production industries at the 4-digit industry level. Several measures are used, including a new simple and intuitive measure of agglomeration. Conditioning on industrial concentration, many of the most geographically concentrated industries are not high-tech industries. We find that the most agglomerated industries are relatively low-tech and that they have lower entry and exit rates and higher survival rates as well as lower job creation and job destruction rates. Within industries we find that the most concentrated region has, on average, lower entry and exit rates but higher job creation rates and lower job destruction rates.

Acknowledgements: The authors would like to thank Stephen Redding, D avid Stout and John Van Reenen for helpful comments. The analysis contained in this paper was funded by the Leverhulme Trust under grant F/ 368/ I and the development of the ARD data was funded by the ESRC Centre for Microeconomic Analysis of Fiscal Policy at the Institute for Fiscal Studies. This report has been produced under contract to ONS. All errors and omissions remain the responsibility of the authors.
\end{abstract}

JEL classification: R12, R3

Keywords: geographic concentration, agglomeration

Correspondence: m.p.devereux@ warwick.ac.uk; rgriffith@ifs.org.uk; hsimpson@ifs.org.uk; IFS, 7 Ridgmount Street, London, WC1E 7AE UK. 


\section{Executive Summary}

There are many examples of industries that are geographically concentrated. Although much attention and policy interest is currently focussed on high-tech clusters, such as in Silicon Valley (California) and Sophia Antipolis (France), the phenomenon is not limited to high-tech industries.

This paper describes patterns of geographic concentration in UK production industries at the 4-digit industry level, using employment data from the population of production plants in the UK, for the year 1992.

We use alternative existing measures of geographic concentration, and present a new measure, which is both simple and informative. This new measure allows us to investigate how much of observed geographic concentration of an industry can be explained by industrial concentration. That is, it enables us to distinguish between industries that are geographically concentrated due to the presence of a single large plant in a particular region, and those that are geographically concentrated due to a number of smaller, unrelated plants in a region. The theoretical literature that emphasises incentives for firms to locate near to each other, points to the second case as being particularly interesting. We define the 'excess' of geographic concentration over industrial concentration as the extent to which an industry is 'agglomerated'. We also examine the extent of 'co-agglomeration' - that is geographic concentration between two or more industries.

As has been found in studies using US and French data, we also find a significant degree of geographic concentration in some industries. In some cases this is almost entirely explained by high industrial concentration. But in others, such as ceramics and lace, high geographic concentration is combined with low industrial concentration.

Using data from 1985 to 1992 we find patterns of agglomeration to be highly persistent. We examine differences in plant entry and exit and job creation and job destruction between agglomerated and non-agglomerated industries. We also look within 4-digit industries at how these factors are acting to re-enforce or reduce the extent of agglomeration. 


\section{Introduction}

There are many examples of geographically concentrated industries, including the often cited clusters of high-tech firms in Silicon Valley (California), Route 128 (Boston), Cambridge (UK) and Sophia Antipolis (France). But the phenomenon is neither recent, nor restricted to high-tech industries. O ther examples abound: the US carpet industry in Dalton, Georgia; the UK ceramics industry around Stoke-on-Trent, an area known as "The Potteries"; the UK lace industry centred in Nottingham. There are also examples of industries clustering across countries, e.g. the financial centres in London, Tokyo and New York.

Understanding how and why these clusters form and persist is an issue of considerable interest both from an academic and policy perspective. In this paper we use plant level data to describe the geographic distribution of production activity in the UK. We consider how much of the geographic concentration that is observed can be explained by industrial concentration.

Alternative measures of geographic concentration are used and a new measure, which is both simple and informative, is proposed. This measure allows us to distinguish between industries where activity is concentrated in one region because: (i) a large number of (smaller) unrelated plants are located there, and (ii) one (or a small number) of larger plants are located there. This distinction is important as our main interest lies in studying the role of externalities in the formation and persistence of agglomerations. This means that we are primarily interested in the case where non-related plants choose to locate near to each other. However, it is worth noting that the second case may have arisen endogenously because the externalities were so great a firm chose to internalise them by purchasing all plants. We use the term "agglomeration" in this paper to refer to geographic concentration over and above that which would be expected given the pattern of industrial concentration in the industry; a more precise definition and measure is given in Section 2.

The extent of geographic concentration, and the reasons for it, has implications for a broad range of policy issues. Throughout the world governments expend considerable sums with the aim of attracting firms or industries to specific locations. For example, the UK has Regional Development Agencies, although within the European Union the 
process is controlled by provisions on state aids. In the US individual State governments offer enticements of various forms for firms to relocate to their region. ${ }^{1}$

If firms have incentives to locate near to other firms within the same or other industries, then there are several policy implications. First, if one region can create a location which new entrants want to join, then there may be large potential gains for that region. Second, if this process has already occurred, it may be prohibitively expensive for a region - and outweigh any gains it may perceive - to try to attract activity from an industry which is already localised elsewhere. Third, how large an impact clusters have on productivity and technology transfer between firms is important in assessing any gains or losses that might result from using fiscal policy to distort firms' location choices.

This paper investigates geographic concentration and agglomeration using a cross section of data for the year 1992. Part of the observed difference in geographic concentration between industries is likely to reflect the different pattern of their development. For well established industries the pattern of geographic concentration observed now will depend on the entire history of that industry and the dynamic processes that shaped it. We also have relatively new industries, which are in earlier stages of their development, the location of which will reflect more recent factors. However, in this paper, we analyse only the position in 1992. In future work we hope to consider the dynamic aspects of agglomeration and clustering more explicitly.

The layout of the paper is as follows. The next section discusses some methodological issues involved in measuring geographic concentration, agglomeration and coagglomeration. Section 3 describes the plant level data, presents measures of the geographic concentration of total production activity in the UK and uses a number of measures to look at patterns of geographic and industrial concentration at the 2-digit and 4-digit industry level. Section 4 looks at plant entry and exit, and section 5 summarises and concludes.

${ }^{1}$ See, inter alia, Hines (1996) and Head, Ries and Swenson (1995). 


\section{Measures of geographic concentration and agglomeration}

There are numerous statistical measures that aim to summarise inequality and concentration in distributions, and these have been applied to many economic issues. For example, the Herfindahl index is a commonly used measure of industrial concentration and the $\mathrm{G}$ ini coefficient ${ }^{2}$ has been used to describe geographic concentration. ${ }^{3}$ More recent papers by Ellison and Glaeser (1997) and Maurel and Sedillot (1999) have proposed indices which are specifically designed to measure agglomeration - that is geographic concentration conditional on industrial concentration. In this section we discuss these measures and some of their properties and propose a new measure of agglomeration which is similar to that of Ellison and Glaeser and that of Maurel and Sedillot but which we find both simpler and more intuitive. In section 3 we apply these measures to UK plant level data.

The alternative measures we discuss are:

- an agglomeration index proposed by Ellison and Glaeser (1997), $\gamma_{E G}$;

- an agglomeration index proposed by Maurel and Sedillot (1999), $\gamma_{M S}$;

- a new agglomeration index, $\alpha$, based on measures of industrial $(M)$ and geographic $(F)$ concentration;

- a locational Gini coefficient, calculated both relative to total manufacturing $\left(L_{R}\right)$ and absolute $\left(L_{A}\right)$;

- a coagglomeration measure proposed by Ellison and G laeser (1997), $\gamma_{E G}^{C}$;

- an alternative coagglomeration measure, $C(r)$.

In the Appendix we also consider a concentration index, denoted $C I$, which is the proportion of firms in the top 3 regions in each industry.

\footnotetext{
2 The Gini coefficient is a measure often used to describe inequality in the distribution of income across a population. 3 See, inter alia, Krugman (1991b) and Amiti (1998).
} 
There are three main distinguishing features between these measures. The first is whether they are a measure of geographic concentration or agglomeration. The Gini coefficients and concentration index are measures of geographic concentration, they do not condition on industrial concentration, while the others are all measure of agglomeration, that is they look at geographic concentration conditional on industrial concentration. A second difference is that the Ellison and Glaeser (1997) and Maurel and Sedillot (1999) measures are both explicitly derived from an underlying location choice model of firm behaviour, while the others (including ours) are not.

The third difference lies in what underlying geographic distribution the observed distribution is compared to. In most empirical work on industry location, the Gini coefficient is measured relative to the geographic distribution of total manufacturing - see, for example, Krugman (1991b) and Amiti (1998). They use a relative Gini, so that they measure the distribution of employment in an industry relative to the distribution of total manufacturing employment. Hence the Gini takes a value of zero if the industry's employment is located in each region in the same proportion as total manufacturing employment. If manufacturing activity is not uniformly distributed, then an industry which was uniformly spread over all regions would appear as being geographically concentrated since it would have a relatively high proportion of employment in regions which had little other activity.

Ellison and Glaeser (1997) and Maurel and Sedillot (1999) also calculate their measures relative to total manufacturing. Ellison and Glaeser (1997) develop an index which they state, "is scaled so that it tak es on a value of zero not if employment is uniformly spread across space, but instead if employment is only as concentrated as it would be ex pected to be had the plants in the industry chosen locations by throwing darts at a map" (p.890). This seems puzzling, however, as in practice their index is based on the difference between the proportion of the industry's employment in each region and the proportion of total manufacturing employment in each region. Maurel and Sedillot (1999) propose an index very similar to Ellison and Glaeser, except that it is derived from an estimator of the probability that two plants in the same industry will be located in the same region. Both measures control for the degree of industrial concentration, and are hence both are measures of agglomeration, rather than geographic concentration. 
We propose a simpler and more intuitive approach. ${ }^{4}$ As in the other two papers, we aim to test alternative theories of geographic concentration and agglomeration against the null hypothesis that the distribution of production activity is randomly distributed. D ivergences from this distribution may reflect some process by which firms in the same industry locate near to each other. But before we proceed we need to consider more precisely what we mean by a "random distribution".

Consider $\mathrm{K}$ geographic regions of equal geographic size and an industry with $\mathrm{N}$ plants. Then the process of "throwing darts at a map" would imply that plants are distributed randomly in geographic space. Plants would be randomly allocated to regions and the expected number of plants in each region would be $\mathrm{N} / \mathrm{K}$ - that is in expectation a uniform distribution. However, an alternative definition of "randomly distributed" is to consider that the location of plants is determined by the location of individuals whom are chosen randomly to set up plants; and that they do so in the region where they reside. This is attractive given the high degrees of observed geographic concentration both with regard to industry employment and the total population, relative to land space. In this paper we follow the approach based on total population. That is, we use regions - based on UK postcodes - which vary in the geographic area they cover, and which are roughly based around urbanisations. We assume that a firm is equally likely to choose to locate in any of these regions, so defined; hence the probability of choosing any given region is $1 / \mathrm{K}$.

We can now define a number of alternative measures. A starting point is the Herfindahl index of industrial concentration, ${ }^{5}$ defined for an individual industry as:

$$
H=\sum_{n=1}^{N} z_{n}^{2}
$$

which measures the distribution of plant size, where $z_{n}$ is the $\mathrm{n}^{\text {th }}$ plant's share of industry employment (or any other size measure), $n=1 \ldots N$. The value of the Herfindahl is determined both by the number of plants in the industry and the size distribution of those

\footnotetext{
${ }^{4}$ In a separate paper, D umais, Ellison and Glaeser (1997), they state that their measure can be closely approximated with something very similar to what we are proposing here.

5 The Herfindahl is a widely used measure of industrial concentration, although there are alternative measures.
} 
plants. For an industry with $N$ firms, the Herfindahl index has a minimum value of $1 / N$, reflecting equally sized firms. Therefore in general the Herfindahl will be higher for industries that have a small number of firms.

A natural analogue of this measure for geographic concentration is

$$
\mathrm{J}=\sum_{\mathrm{k}=1}^{\mathrm{K}} \mathrm{s}_{\mathrm{k}}^{2}
$$

where $s_{k}$ is the $k^{\text {th }}$ region's share of industry employment, $k=1 \ldots \mathrm{K}$. O ne natural way to examine the agglomeration of an industry - that is, geographic location conditional on industrial concentration - would be simply to consider the difference between these two measures: J $\cdot \mathrm{H}$.

Such a measure is attractive for the case in which $\mathrm{N}<\mathrm{K}$. Suppose for example that there is an arbitrary size distribution of $\mathrm{N}$ plants, but with only one plant in any single region. In this case $\mathrm{J}=\mathrm{H}$ and hence the difference is zero. This coincides with a natural measure of agglomeration: in this case, although there is an unequal distribution of production activity across regions, this can be wholly explained by differences in the size of firms - industrial concentration rather than geographic concentration. However, this measure is less attractive for the case in which $N>K$. Suppose for example that there were $N$ equally sized firms equally distributed between regions, but that $\mathrm{N}>\mathrm{K}$. In this case $\mathrm{J}>\mathrm{H}$ : since $\mathrm{J}-\mathrm{H}>0$, the measure suggests - incorrectly - that the industry is agglomerated.

This problem can be overcome using measures related to the coefficient of variation (CV ). To see this, begin with the relationship between the Herfindahl index and the coefficient of variation, and define a measure $M$ such that:

$$
M=\sum_{n=1}^{N}\left(z_{n}-\frac{1}{N}\right)^{2}=\frac{C V\left(z_{n}\right)^{2}}{N}=H-\frac{1}{N}
$$

where $\mathrm{CV}\left(\mathrm{z}_{\mathrm{n}}\right)^{2}$ is the squared coefficient of variation of the share in employment of each plant in the industry. A similar relationship exists for the geographic equivalent, J:

$$
\mathrm{G}=\sum_{\mathrm{k}=1}^{\mathrm{K}}\left(\mathrm{s}_{\mathrm{k}}-\frac{1}{\mathrm{~K}}\right)^{2}=\frac{\mathrm{CV}\left(\mathrm{s}_{\mathrm{k}}\right)^{2}}{\mathrm{~K}}=\mathrm{J}-\frac{1}{\mathrm{~K}}
$$


where CV $\left(s_{\mathrm{k}}\right)^{2}$ is the squared coefficient of variation of the shares in employment in each region in the industry. $\mathrm{M}$ measures the distribution of employment across plants in the industry, controlling for the number of plants. Any uniform distribution of employment across plants would yield $H=1 / N$ and hence $M=0$, irrespective of $N$. Similarly, $\mathrm{G}$ measures the distribution of employment across regions, controlling of the number of regions. Any uniform distribution of employment across regions would yield $\mathrm{J}=1 / \mathrm{K}$ and hence $\mathrm{G}=0$, irrespective of $\mathrm{K}$. In fact, the measure of $\mathrm{G}$ shown in equation (4) is very close to equivalent measures - also denoted G - in Ellison and Glaeser (1997) and Maurel and Sedillot (1999). Each of these other papers attempts to control for differences in the size of regions - measured by total employment. The difference between them is in the way that they control for such differences. However, in the case where regions are all of equal size, then both measures in these other two papers reduce to the definition of $G$ in (4).

The difference between $\mathrm{G}$ and $\mathrm{M}$ might be seen as an alternative measure of agglomeration to the difference between $\mathrm{J}$ and $\mathrm{H}$. However, in the case in which $\mathrm{N}<\mathrm{K}$, the maximum number of regions in which a plant might be sited is $\mathrm{N}$ rather than $\mathrm{K}$. This makes no difference to the computation of $J$ since adding regions with no employment leaves J unaffected. However, it clearly affects G. For the purposes of considering agglomeration we therefore make use of a term $\mathrm{K}^{*}=\min [\mathrm{N}, \mathrm{K}]$, which is the maximum number of regions in which an industry might be located, given $\mathrm{N}$ and $\mathrm{K}$. This suggests an adjustment to the measure of $G$. Instead of using $G$ we define a measure $F$ as an index of geographic concentration:

$$
\mathrm{F}=\sum_{\mathrm{k}=1}^{\mathrm{K}^{*}}\left(\mathrm{~s}_{\mathrm{k}}-\frac{1}{\mathrm{~K}^{*}}\right)^{2}=\mathrm{J}-\frac{1}{\mathrm{~K}^{*}}
$$

We define $\mathrm{F}$ as a measure of geographic concentration and $\mathrm{M}$ as a measure of industrial concentration, where $\mathrm{F}$ controls for the maximum number of regions in which employment may be located and $M$ control for the total number of plants. To see the main implication of using $F$ rather than $G$, consider two industries, A which has 2 equally-sized firms located in different regions and B which has 10 equally-sized firms located in different regions. Suppose that $\mathrm{K}=100$. For both industries, $\mathrm{F}=0$, reflecting 
their equal distribution across regions. However, for industry A, G =0.24 and for industry $B, G=0.09$.

A natural measure of "agglomeration" - or excess geographic concentration - is the difference between $\mathrm{F}$ and $\mathrm{M}$ :

$$
\alpha=F-M .
$$

$\alpha$ lies between -1 and +1 . It takes on positive values if our measure of the distribution of employment across regions $(F)$ exceeds that across plants $(M)$ - this is a more precise definition of what we mean by agglomeration. The opposite is also clearly true: it takes negative values if $\mathrm{F}<\mathrm{M} .{ }^{6}$ If both distributions are uniform, then $\alpha=F=M=0$. More generally, $\alpha=0$ whenever the distributions across plants and regions are equal $(F=M)$.

This measure is closely related to those of Ellison \& Glaeser (1997) and Maurel and Sedillot (1999). Ellison \& Glaeser (1997) use a term $G_{E G}=\sum_{k=1}^{K}\left(s_{k}-x_{k}\right)^{2}$, where $x_{k}$ is the $\mathrm{k}^{\text {th }}$ region's share of total manufacturing employment, $\mathrm{k}=1 \ldots \mathrm{K}$ and define an index of agglomeration as

$$
\gamma_{\mathrm{EG}}=\frac{\mathrm{G}_{\mathrm{EG}} /(1-\mathrm{X})-\mathrm{H}}{(1-\mathrm{H})}
$$

where $X=\sum_{k=1}^{K} x_{k}^{2}$. For large and reasonably uniform $K, \quad X \rightarrow 0$, and $\gamma_{\mathrm{EG}} \rightarrow\left(\mathrm{G}_{\mathrm{EG}}-\mathrm{H}\right) /(1-\mathrm{H})$. There are three main differences from our measure of agglomeration, $\alpha$. First, this has a scaling term $(1-H)$. Second, $G_{E G}$ attempts to control for differences in overall size - measured by total manufacturing employment across regions. Third, this measure is based on a comparison of $\mathrm{G}$ and $\mathrm{H}$; from the analysis above, however, it seems more natural to compare $G$ with $M$, and $H$ with $J$. This is because $\mathrm{H}$ and $\mathrm{J}$ are both defined in terms of the sum of squared shares of industry employment, and $G$ and $M$ are both defined relative to the mean (or uniform) share. Maurel and Sedillot (1999) develop an index which has an identical expression to (7) -

\footnotetext{
6 This can arise if, for example, and industry is uniformly distributed geographically, so that $F=0$, but is industrially concentrated, $M=0$. For an extreme example, suppose that $K=2, N=4$ with 2 firms having employment of 999 each and 2 firms having employment of 1 each. If each region contains one of each type of firm, then $J=0.5, F=G=0, H=0.48$, $\mathrm{M}=0.46$ and $\alpha=-0.46$.
} 
denoted below as $\gamma_{\mathrm{MS}}$ - but with replaces Ellison and Glaeser's $\mathrm{G}_{\mathrm{EG}}$ term with $G_{M S}=\sum_{k=1}^{K} s_{i}^{2}-\sum_{k=1}^{K} x_{i}^{2}{ }^{7}$. This measure has the same properties as Ellison and G laeser's; it differs in that it is derived from an estimator of the probability that two plants in the same industry will be located in the same region.

All of these measures are based on the geographic proximity of firms within the same industry. However, it is possible that any externalities which generate geographic concentrations within an industry might also generate geographic concentrations between two or more industries. This may be the case if two industries are vertically related, for example. It is of course possible to use the measures above to analyse the overall pattern of geographic and industrial concentration for any set of firms, whether they come from one or more industries. However, it is also useful to consider the extent to which concentrations arise within and between specific industries. Following the approach of Ellison and Glaeser (1997) we term the concentration between industries as coagglomeration. Their measure of coagglomeration is based on the difference between $G_{E G}$ applied to the group of industries and the weighted average of $G_{E G}$ for each individual industry, where the weights are based on the size of each industry. It is possible to show that their measure of the coagglomeration of $r$ industries is equal to:

$$
\gamma_{E G}^{C}=\frac{G_{E G r}-\sum_{j=1}^{r}\left\{G_{E G j} w_{j}^{2}\right\}}{(1-X)\left(1-\sum_{j=1}^{r} w_{j}^{2}\right)}
$$

where $\mathrm{w}_{\mathrm{i}}=\mathrm{T}_{\mathrm{i}} / \sum_{\mathrm{j}=1}^{\mathrm{r}} \mathrm{T}_{\mathrm{j}}$ and $\mathrm{T}_{\mathrm{i}}$ is total employment in industry $\mathrm{i}$, and where $\mathrm{G}_{\mathrm{EGr}}$ is Ellison and Glaeser's measure applied to the overall set of industries, r. In the special case assumed above, in which underlying employment is assumed to be uniformly distributed across regions, so that $G_{E G}=G$ as defined in (4), then for $r=2$ and industries $A$ and $B$, it is possible to show that $\gamma_{\mathrm{EG}}^{\mathrm{C}}=\mathrm{K}^{2} \operatorname{cov}\left(\mathrm{s}_{\mathrm{A}}, \mathrm{s}_{\mathrm{B}}\right) /(\mathrm{K}-1) .8$

${ }^{7}$ Strictly, Maurel and Sedillot define their measure relative to (1-X ).

${ }^{8}$ D erivations of these expressions are available on request from the authors. 
In effect then, the Ellison and Glaeser measure is close to the covariance of the shares of employment in each industry across regions. This is intuitive: two industries with a random geographic distribution would tend to generate a covariance of zero and hence $\gamma_{\mathrm{EG}}^{\mathrm{C}}=0$. If the industries tended to locate in the same regions then $\gamma_{\mathrm{E} G}^{C}>0$, and if they tended to locate in different regions then $\gamma_{\mathrm{E} G}^{\mathrm{C}}<0$.

It is tempting to develop a similar measure of coagglomeration based on $\alpha$ (our proposed measure of agglomeration), rather than $\mathrm{G}$ (the scaled measure of geographic concentration in equation (4)). However, there are two reasons for not doing so. The first is that in analysing coagglomeration, there is no need to differentiate between geographic concentration and agglomeration. In analysing "coagglomeration" we are interested in whether industries are located in the same regions, rather than whether firms in different industries are located in the same regions. ${ }^{9}$ This reflects the fact that, using $\mathrm{w}_{\mathrm{i}}^{2}$ as a weight, then $\mathrm{H}_{\mathrm{r}}-\sum_{\mathrm{i}} \mathrm{w}_{\mathrm{i}}^{2} \mathrm{H}_{\mathrm{i}}^{2}=0$, so this difference plays no role in any coagglomeration measure..$^{10}$ The second is that in analysing coagglomeration, there is no need to control for cases in which either $\mathrm{N}>\mathrm{K}$ or $\mathrm{N}<\mathrm{K}$. This also reflects the fact that we are interested in whether industries are located in the same regions, rather than whether firms in different industries are located in the same regions. It is possible to use the covariance of employment shares in each region to analyse this whether $\mathrm{N}>\mathrm{K}$ or $\mathrm{N}<\mathrm{K}$. Below, we therefore use a slightly simplified version of the Ellison and Glaeser measure as our measure of coagglomeration:

$$
C(r)=\frac{G_{r}-\sum_{i=1}^{r} w_{i}^{2} G_{i}}{\left(1-\sum_{i=1}^{r} w_{i}^{2}\right)} .
$$

In the two firm case, this is

\footnotetext{
${ }^{9}$ Consider two comparisons for example. Industry A consists of 100 equally-sized firms located 10 each in 10 different regions. Industry B consists of 91 firms; 90 firms account for 1\% of total employment in the industry each, and are located 10 each in 9 different regions, while 1 firm accounts for the other 10\% of employment and is located in a different region. In analysing the coagglomeration of each of $\mathrm{A}$ and $\mathrm{B}$ with a third industry $\mathrm{C}$, the differences in industrial concentration are not relevant.

10 That is, it is possible also to consider both the EG measure and our measure as reflecting the difference in $\mathrm{G}-\mathrm{H}$ between the aggregate of all firms and the weighted average of individual industries, since the $\mathrm{H}$ terms cancel out.
} 


$$
C(A, B)=\frac{G_{A+B}-\sum_{i=1}^{2} w_{i}^{2} G_{i}}{\left(1-\sum_{i=1}^{2} w_{i}^{2}\right)}=\sum_{k=1}^{K} s_{A k} s_{B k}-\frac{1}{K}=K \cdot \operatorname{cov}\left(s_{A}, s_{B}\right)
$$

There are two differences: (i) we use the measure of $G$ defined in (4) rather than $G_{E G}$, and (ii) we do not divide by 1-X. In Table 5 below we also present the Ellison Glaeser measure for comparison. Like Maurel and Sedillot (1999) we also attempt to show the proportion of $G_{r}$ which is accounted for by geographic concentration "within" each industry, and "between" the industries. We do so by rearranging (9) to yield:

$$
G_{r}=\sum_{i=1}^{r} w_{i}^{2} G_{i}+\left(1-\sum_{i=1}^{r} w_{i}^{2}\right) C(r)
$$

where the "within" geographic concentration is given by the first term on the RHS of (9b) expressed as a proportion of $G_{r}$ and the "between" geographic concentration is given by the second term on the RHS of (9b) expressed as a proportion of $G_{r}$.

In the next section we focus primarily on empirical estimates of $F, M, \alpha$, and $\gamma_{\mathrm{EG}}$ and $C(\mathrm{r})$. In the Appendices we also show the Maurel and Sedillot measure, $\gamma_{M S}$, and a basic concentration index defined as the proportion of firms in an industry in the top 3 regions, denoted C. For comparison with other work, we also present the "locational Gini coefficient", measured relative to total manufacturing:

$$
L_{R}=\frac{2}{K^{2} \bar{Y}}\left[\sum_{k=1}^{K} \lambda_{k}\left(Y_{k}-\bar{Y}\right)\right]
$$

where $Y_{k}$ is the share of the industry's employment in region $k$ expressed as a proportion of the share of total manufacturing employment in region $\mathrm{k}, \lambda_{k}$ denotes the position of the region in the ranking of $Y_{k}$, and $\bar{Y}$ is its mean across regions. This is the measure used by Krugman (1991b). In general, $0 \leq \mathrm{L} \leq 1$. However, for $\mathrm{N}<\mathrm{K}$ then $1-\mathrm{N} / \mathrm{K} \leq \mathrm{L} \leq 1$. For the purposes of comparison, we also present in the Appendices an "absolute" Gini coefficient, $L_{A}$. This is defined as in (8), except that $\mathrm{Y}_{\mathrm{k}}$ is in this case defined simply as the share of the industry's employment in region $k$ - it is not in this case expressed as a proportion of the share of total manufacturing employment in region $\mathrm{k}$. 


\section{Patterns of geographic and industrial concentration in the UK}

In this section we first discuss the data used, then look at patterns of geographic and industrial concentration in total UK production activity. In the course of presenting these results we discuss a number of issues relating to the appropriate level of industry and regional aggregation. In the final part of this section we summarise the patterns of geographic and industrial concentration at the 4-digit level. Tables with the results for 214 industries are given in Appendix B.

\subsection{The data}

The empirical analysis presented below uses plant level data known as ARD which is the data underlying the Annual Census of Production in the UK. ${ }^{11}$ The ARD contains some basic information on the population of production plants in the UK. ${ }^{12}$ This includes the location of the plant (postcode and local authority), the 4-digit industrial classification and the number of employees. A broader range of information on output and inputs is available at the establishment level. An establishment can be a single plant or a group of plants (which can be at different addresses). This information is available for all establishments with over 100 employees and a sample of those with below 100.

11 Now called the Annual Business Inquiry (ABI).

12 The ARD contains two types of data - non-selected and selected data. To construct a dataset of all production establishments it is necessary to combine the non-selected and selected data. See O ulton (1997) and G riffith (1999) for a description of the ARD data. 
Table 1: Descriptive statistics, 1992

\begin{tabular}{lr}
\hline \hline Number of 4-digit industries & 216 \\
& \\
Number of plants in population & 157,600 \\
Number of plants incorporated & 102,568 \\
Number of plants incorporated \& production & 97,832 \\
Number of plants incorporated \& production \& active & 96,577 \\
Number of "firms" (non-related plants within the same region) & 90,282 \\
Average employment per "firm" & 47 \\
\hline \hline "This is the number of observations after aggregating plants that are in the same industry and \\
postcode and are owned by the same firm.
\end{tabular}

Table 1 shows some descriptive statistics. O ur data includes information on plants in 216 4- digit production industries (using the 1980 SIC classification). These include energy and water supply, extraction and all manufacturing industries.

After combining the non-selected and selected data for 1992 we have a total of 157,600 plants. ${ }^{13}$ From the population of plants, we restrict ourselves to plants which are part of incorporated companies, (thus excluding publicly owned corporations, partnerships, soletraders and charities), plants that are strictly engaged in production activity (rather than distribution or administration), and plants that are active in that year (excluding those that are not yet in production). This leaves us with 99,577 plants. From the theoretical discussion above it is clear that we are interested in looking at agglomerations of plants that are not under common ownership, thus where we observe two plants in the same industry, in the same postcode that are under common ownership we aggregate them and call them a firm. This leaves us with 90,282 firms (non-related plants). ${ }^{14}$

Average employment in these plants in 1992 was 47 employees. Table 2 shows the size distribution of plants. Half of plants have fewer than 10 employees, while 91 percent have fewer than 100 employees.

\footnotetext{
${ }^{13}$ We use the word plant to refer to what is called a local unit in the ARD. We drop 3963 plants which are duplicate entries.

${ }^{14}$ We have also excluded 6 plants in two industries - public gas supply (1620) and nuclear fuel product (1520) - because they contain only one firm (and the confidential nature of the data means that we can not show these industries separately).
} 
Table 2: Size distribution of plants

\begin{tabular}{lrr}
\hline \hline Number of employees & Percentage of plants & Percentage of employment \\
\hline $0-9$ a & 50.6 & 4.2 \\
$10-49$ & 32.6 & 15.7 \\
$50-99$ & 7.6 & 11.3 \\
$100-199$ & 4.7 & 13.9 \\
$200+$ & 4.5 & 54.9 \\
\hline \hline
\end{tabular}

a There are 29 plants with 0 employees.

\subsection{The concentration of total production}

Table 3 shows three measures of agglomeration calculated for total production $-\alpha, \gamma_{M S}$, $\gamma_{E G}$ together with the geographic concentration measures $F$, the locational Gini coefficient, and the concentration index and the industrial concentration measure $M$. One issue that arises in constructing these measures is what level of regional unit to use for analysis. We have data available on both administrative and postcode level.

\section{Table 3: Geographic and industrial concentration measures for total production}

\begin{tabular}{lccc}
\hline \hline & $\begin{array}{c}\text { Local authority } \\
\text { Number of regional units }\end{array}$ & $\begin{array}{c}\text { Postcode } \\
113\end{array}$ & $\begin{array}{c}\text { County } \\
65\end{array}$ \\
\hline & & & \\
$\alpha$ & 0.005 & 0.007 & 0.014 \\
$\mathrm{~F}$ (geographic concentration) $^{\mathrm{a}}$ & 0.0051 & 0.0077 & 0.0143 \\
$\mathrm{M}$ (industrial concentration) & 0.0005 & 0.0005 & 0.0003 \\
$\gamma_{M S}$ & 0.005 & 0.007 & 0.014 \\
$\gamma_{E G}$ & 0.005 & 0.007 & 0.014 \\
Locational Gini & 0.489 & 0.415 & 0.488 \\
Concentration index & 0.308 & 0.326 & 0.416 \\
\hline \hline
\end{tabular}

Notes: Measures are: $\alpha=\mathrm{F}-\mathrm{M}$ : agglomeration measure, F: geographic concentration (equation (5)), $\mathrm{M}$ : industrial concentration (equation (3)), $\gamma_{M S}$ : Maurel and Sedillot (1999) agglomeration measure (p.9), $\gamma_{E G}$ Ellison and Glaeser (1997) agglomeration measure (equation (7)), locational gini (equation (10)), and concentration index (p.4).

The 8 central London postcodes are aggregated to form a single postcode. 14 central London local authorities are aggregated to form a single local authority. G reater London, which covers a larger geographic area, is aggregated to form a single county.

${ }^{\mathrm{a}}$ The level of industrial concentration can change with different geographic regions because of the way we construct "firms" (non-related plants).

There are three levels of administrative regions in the UK: region (11), county (65) and local authority (446). Column two uses local authority boundaries to define geographic regions. Column three uses counties (these are broadly like US States). The geographic region we prefer is the postcode area. This is the first two letters of the postcode, for 
example S for Sheffield and BS for Bristol. ${ }^{15}$ This is used in column two. Postcode areas correspond most closely to travel to work areas and areas of local economic activity (these are similar to US metropolitan areas). This gives us geographic areas that cross local authority and county borders and which are centred around cities or towns, which we might think of as centres of economic activity. Appendix C, Map 1 shows the geographic distribution of production employment over postcode areas.

In general, moving to a larger geographic unit increases the geographic concentration measure F, and consequently $\alpha$. Similarly $\gamma_{M S}, \gamma_{E G}$ and the concentration index also increase as the number of geographic regions decreases. In calculating the $\mathrm{G}$ ini coefficient we are faced with the problem of what to do with industry-regions where there is no activity (not all industries have plants in every postcode). We can either calculate the Gini only across those regions in which there is some activity, or we can treat each of the 113 postcode areas as a possible location, and if an industry has no activity in a particular region assign it a zero. We take the latter approach.

\subsection{Agglomeration at the industry level}

In this section we describe patterns of agglomeration at the 4-digit industry level for 1992. We present our proposed measure of agglomeration, $\alpha$, and its components - geographic concentration $(F)$ and industrial concentration $(M)$ - and the Ellison and Glaeser measure, $\gamma_{E G}$ which is defined relative to the geographic distribution of total manufacturing employment. Appendix B lists all the measures discussed for each industry.

Figure 1 shows the distributions of the $\alpha, F, M$ and $\gamma_{E G}$ across 4 -digit industries. The two agglomeration measures - $\alpha$ and $\gamma_{E G}$ - have similarly skewed distributions. None of the industries have a value of $\alpha$ below zero, and over half the values lie between 0 and 0.017. However, over 25 industries have a value of $\gamma_{E G}$ below zero, with half lying below 0.008. Geographic concentration, F, is less skewed than industrial concentration.

\footnotetext{
15 Each UK postcode identifies an average of 15 individual delivery points. They have four levels. There are 124 areas which have an average of 183,000 delivery points. These are divided into 2,900 districts of which there are an average of 21 per area and which have an average of 8,197 delivery points within them. These are further broken down into 9,000 sectors and within this into units. For example, the post code GU9 8AQ is in the area GU (Guildford), the district GU9, the sector G U9 8 and the units are identified by GU9 8AQ.
} 

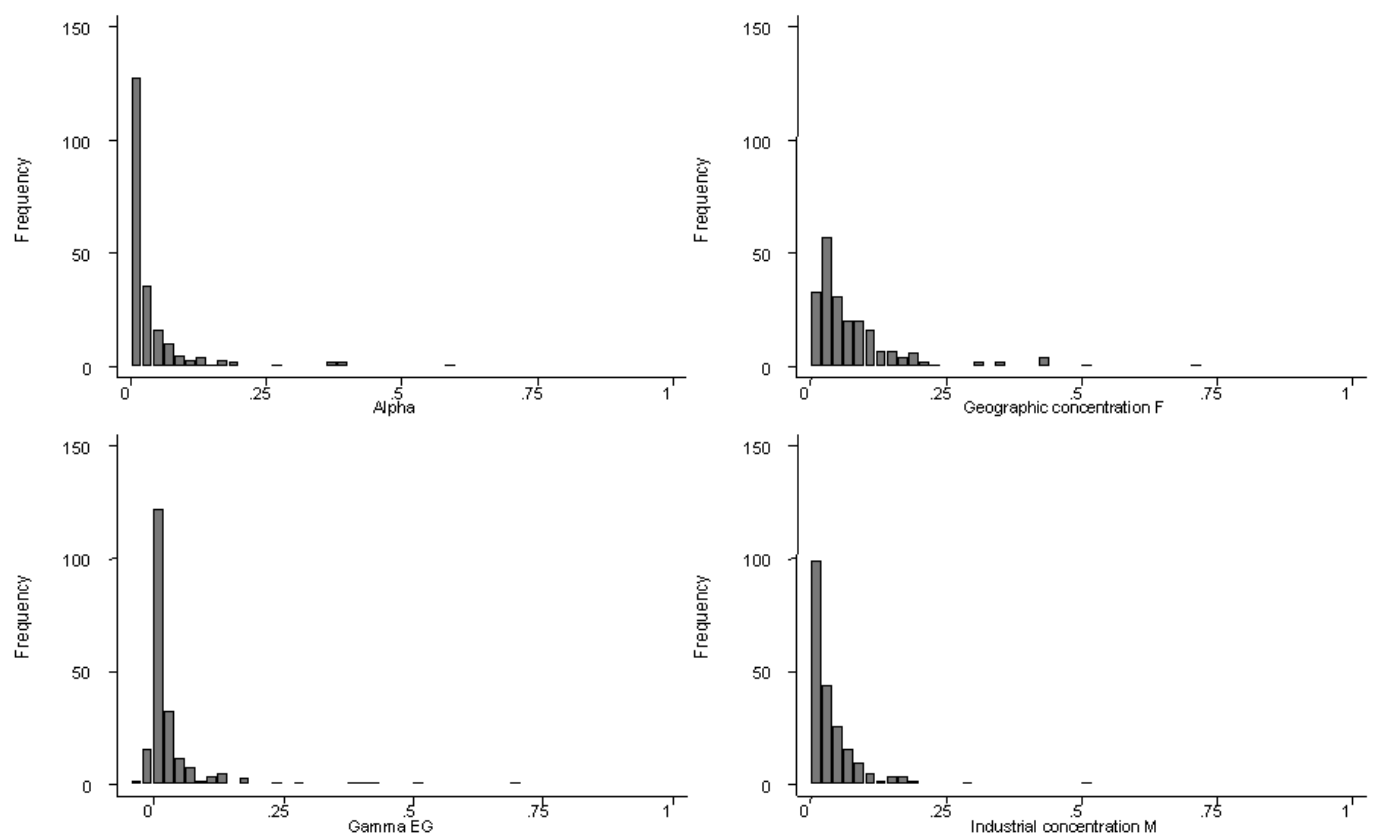

Figure 1: Distribution of measures

Appendix A presents the correlation between each of the measures and the number of firm level observations in each industry. The correlations between the three agglomeration measures are all positive and very high, despite the fact that $\gamma_{M S}$, and $\gamma_{E G}$ are defined as relative to manufacturing industry as a whole. However, as would be expected, the correlation with the number of firms in the industry is, in each case, low. By contrast, there is a strong negative correlation between the locational Ginis, $L_{R}$ and $L_{A}$, and the number of firms, and a weaker correlation between the concentration index, $\mathrm{C}$ and the number of firms in the industry.

While the correlations indicate similarities between the measures, it is also important to ascertain whether they rank industries similarly according to the degree to which they are agglomerated. Table A2 presents rank correlations between the measures. Again there is a strong positive correlation between each of the three agglomeration measures.

Table 4 summarises the pattern of agglomeration at the 4-digit industry by showing the means of $\alpha$ and $\gamma_{E G}$ (across 4-digit industries) for each 2-digit industry, and the 
percentage of 4-digit industries in each quartile of $\alpha$ across all 4-digit industries (the fourth quartile containing the most agglomerated industries). The 2-digit industries are ordered by the mean of $\alpha$. We use $\alpha$, in order to identify agglomerated industries, as it can be interpreted intuitively when broken down into its components $\mathrm{F}$ and $\mathrm{M}$ geographic and industrial concentration, as in Table 6. We also report $\gamma_{E G}$, in order to compare our results with those for the US and France which use this measure.

Textiles (43) and Extraction of other minerals (23) top the table with mean values of $\alpha$ far in excess of all other 2-digit industries. The 4-digit industry spinning and weaving (4340) is in fact the most agglomerated industry (see Table 6) and 11 of the other 4-digit industries within textiles are in the fourth quartile. Textiles are found to be highly agglomerated in many countries. ${ }^{16}$ The agglomeration of extraction of minerals (this includes stone, clay, sand, gravel, salt) on the other hand is clearly driven by the fact that their main inputs are physically immobile and geographically concentrated. The other notable feature of Table 4 is the group of industries at the bottom of the table with very low mean $\alpha$ - water supply (17) and manufacture of office equipment (33). In general, it appears that less technologically advanced industries are more agglomerated, while the more technology oriented ones are not. For example, if we use the proportion of investment that is spent on computer purchases ${ }^{17}$ as an indicator of technological sophistication, and correlate it with our agglomeration measure $\alpha$ we find a negative and significant correlation.

16 See Maurel and Sedillot (1999) Table 2, Elison and Glaeser (1997), Table 4, Krugman (1991b) Appendix D.

17 Taken from the selected ARD sample, the proportion of computer investment is calculated at the plant level and averaged across all plants within each 4-digit industry. The average proportion ranges from -88\% (3246 process engineering contractors) to 64\% (3286 other industrial and commercial machinery). 
Table 4: Summary of agglomeration in 4-digit industries, by 2-digit industry

\begin{tabular}{|c|c|c|c|c|c|c|c|}
\hline \multirow[t]{2}{*}{ 2-digit industry } & \multirow[t]{2}{*}{ Mean $\alpha$ a } & \multicolumn{4}{|c|}{$\begin{array}{r}\% \text { of 4-digit industries in } \\
\text { quartile (by } \alpha \text { ) }\end{array}$} & \multirow{2}{*}{$\begin{array}{c}\text { Mean } \\
\gamma_{E G}\end{array}$} & \multirow[t]{2}{*}{$\begin{array}{r}\text { Number of } 4 \\
\text { digit industries }\end{array}$} \\
\hline & & 1 & 2 & 3 & 4 & & \\
\hline 43 Textiles & 0.160 & 0 & 7 & 13 & 80 & 0.168 & 15 \\
\hline 23 Extraction of other & 0.145 & 0 & 0 & 33 & 67 & 0.192 & 3 \\
\hline 31 Manufacture of other & 0.060 & 0 & 21 & 43 & 36 & 0.051 & 14 \\
\hline 24 Manufacture non-metal & 0.051 & 25 & 33 & 17 & 25 & 0.045 & 12 \\
\hline 44 Leather & 0.050 & 0 & 0 & 50 & 50 & 0.037 & 2 \\
\hline 26 Production of man-ma & 0.048 & 0 & 0 & 0 & 100 & 0.043 & 1 \\
\hline 35 Motor vehicles and p & 0.045 & 0 & 40 & 20 & 40 & 0.041 & 5 \\
\hline 47 Paper and paper prod & 0.045 & 9 & 36 & 27 & 27 & 0.034 & 11 \\
\hline 14 Mineral oil processing & 0.044 & 0 & 0 & 0 & 100 & 0.040 & 2 \\
\hline 16 Production and distr & 0.044 & 0 & 0 & 0 & 50 & 0.001 & 1 \\
\hline 22 Metal manufacture & 0.043 & 0 & 0 & 43 & 57 & 0.031 & 7 \\
\hline 36 Manufacture of trans & 0.042 & 0 & 33 & 50 & 17 & 0.038 & 6 \\
\hline 45 Footwear and clothing & 0.042 & 0 & 23 & 46 & 31 & 0.031 & 13 \\
\hline 49 other manufacturing & 0.037 & 29 & 29 & 29 & 14 & 0.022 & 7 \\
\hline 41 Food drink and toba & 0.032 & 23 & 15 & 23 & 38 & 0.023 & 13 \\
\hline 42 Sugar and its by-pro & 0.019 & 36 & 45 & 9 & 9 & 0.010 & 11 \\
\hline 48 Rubber and plastic & 0.018 & 67 & 11 & 11 & 11 & 0.014 & 9 \\
\hline 32 Mechanical engineering & 0.017 & 35 & 23 & 35 & 8 & 0.010 & 26 \\
\hline 25 Chemical industry & 0.014 & 30 & 40 & 25 & 5 & 0.008 & 20 \\
\hline 34 Electrical and elect & 0.014 & 47 & 27 & 13 & 13 & 0.009 & 15 \\
\hline 37 Instrument engineering & 0.014 & 50 & 17 & 33 & 0 & 0.008 & 6 \\
\hline 11 Coal extraction and & 0.011 & 50 & 0 & 50 & 0 & 0.014 & 2 \\
\hline 46 Timber and wood & 0.009 & 44 & 56 & 0 & 0 & 0.002 & 9 \\
\hline 33 Manufacture of office & 0.007 & 50 & 50 & 0 & 0 & 0.004 & 2 \\
\hline 17 Water supply industry & 0.003 & 100 & 0 & 0 & 0 & -0.031 & 1 \\
\hline
\end{tabular}

Notes: Q uartiles boundaries are by $\alpha, 1:(0,0.0092), 2:(0.0093,0.0168), 3:(0.0171,0.0378), 4:(0.0381$, 0.5929).

Measures are: $\alpha=F-M$ : agglomeration measure (equations (3), (5)), and $\gamma_{E G}$ : Ellison and Glaeser (1997) agglomeration measure (equation (7)).

a Mean is unweighted.

An alternative analysis of a 2-digit industry group is to consider the measures of coagglomeration discussed above. Table 5 shows our measure of co-agglomeration calculated for 2-digit industry groups (column 1). It also shows the geographic concentration of the 2-digit industry, $G_{r}$ (column 2), the percentage of $G_{r}$ accounted for by "between" sub-industry variation (column 3), and the Ellison and Glaeser measure of coagglomeration.

There is a considerable difference in the extent to which 2-digit industries have a high degree of geographic concentration $\left(\mathbb{G}_{\mathrm{r}}\right)$, and in the extent to which they exhibit coagglomeration of their 4-digit sub-industries, although these two measures are clearly positively correlated. However, 2-digit industries with a high geographic concentration differ in how far that this is driven by "between" industry geographic concentration. Paper and paper products (47) exhibits both high co-agglomeration with a high proportion due to geographic concentration between its 11 sub-industries. "Between" industry concentration could be driven by a number of factors including vertical relationships, 
shared technology or skills, or a similar geographic distribution of demand. However for the two primary product 2-digit industries with the highest geographic concentration, this is mainly due to "within" 4-digit industry geographic concentration. The Ellison and Glaeser measure, which is calculated relative to the geographic distribution of employment, produces a similar ranking of the 2-digit industry groups to our absolute measure.

\section{Table 5: Co-agglomeration by 2-digit industry}

\begin{tabular}{|c|c|c|c|c|}
\hline 2-digit industry & $\mathrm{C}(\mathrm{r})$ & $\mathbf{G}_{r}$ & $\begin{array}{r}\text { \% " between" 4-digit } \\
\text { industries }\end{array}$ & $\gamma_{E G}^{C}$ \\
\hline 14 Mineral oil processing & 0.053 & 0.096 & 25.3 & 0.051 \\
\hline 11 Coal extraction & 0.042 & 0.356 & 1.3 & 0.042 \\
\hline 44 Leather & 0.030 & 0.049 & 29.9 & 0.021 \\
\hline 35 Motor vehicles and parts & 0.023 & 0.046 & 28.7 & 0.015 \\
\hline 43 Textiles & 0.023 & 0.044 & 43.3 & 0.018 \\
\hline 47 Paper and paper prod & 0.023 & 0.026 & 74.6 & 0.011 \\
\hline 31 Manufacture of other & 0.023 & 0.025 & 80.7 & 0.013 \\
\hline 22 Metal manufacture & 0.022 & 0.040 & 42.5 & 0.013 \\
\hline 45 Footwear and clothing & 0.014 & 0.019 & 63.4 & 0.004 \\
\hline 24 Manufacture non-metal & 0.012 & 0.034 & 30.7 & 0.007 \\
\hline 49 o ther manufacturing & 0.012 & 0.017 & 58.3 & 0.002 \\
\hline 33 Manufacture of office & 0.007 & 0.031 & 4.0 & 0.008 \\
\hline 37 Instrument engineering & 0.007 & 0.010 & 42.2 & 0.003 \\
\hline 25 Chemical industry & 0.007 & 0.010 & 57.2 & 0.005 \\
\hline 41 Food, drink and tobacco & 0.006 & 0.008 & 57.4 & 0.003 \\
\hline 32 Mechanical engineering & 0.006 & 0.007 & 80.0 & 0.001 \\
\hline 42 Sugar and its by prod & 0.005 & 0.010 & 37.6 & 0.000 \\
\hline 46 Timber and wood & 0.005 & 0.007 & 53.7 & 0.000 \\
\hline 48 rubber and plastic & 0.005 & 0.007 & 52.7 & 0.001 \\
\hline 34 Electrical and elec & 0.004 & 0.007 & 58.3 & 0.002 \\
\hline 36 Manufacture of trans & 0.003 & 0.023 & 6.2 & 0.001 \\
\hline 23 Extraction of other & 0.001 & 0.038 & 1.6 & 0.002 \\
\hline 26 Production of man-ma & - & 0.138 & 0 & - \\
\hline 16 Production and distri & - & 0.120 & 0 & - \\
\hline 17 Water supply industry & - & 0.095 & 0 & \\
\hline
\end{tabular}

Note: Measures are: $C(\mathrm{r})$ : coagglomeration (equation $(9)), \mathrm{G}_{\mathrm{r}}$ geographic concentration (equation $\left.(9 \mathrm{~b})\right), \%$ "between" 4-digit industries given by $\left[\left(1-\sum_{i=1}^{r} w_{i}^{2}\right) C(r)\right] / G_{r}$ (equation (9b)), and $\gamma_{E G}^{C}$ : Ellison and G laeser coagglomeration measure (equation (8)).

Table 6 shows the 20 most agglomerated 4-digit industries as measured by $\alpha$. The table shows the number of firms in each industry, the geographic concentration measure, $F$, the industrial concentration measure, $M$, and again $\gamma_{E G}$. Appendix C, Maps 2-5, show the geographic distribution of employment for the 4 digit industries 2489 (ceramic goods), 4395 (lace), 4910 (jewellery), and 4363 (hosiery). 
While all of these industries display high geographic concentration, it is interesting to note the variation in industrial concentration $(M)$. For example, ceramic goods (2489), has high geographic concentration and low industrial concentration and thus appears second in the table in terms of agglomeration. Pedal cycles (3634), on the other hand, has quite high geographic concentration coupled with high industrial concentration, and so appears much lower down the table.

\section{Table 6: 20 most agglomerated industries}

\begin{tabular}{lrcccr}
\hline \hline 4-digit industry & $\begin{array}{r}\text { Number of } \\
\text { firms }\end{array}$ & $\boldsymbol{\alpha}$ & $\mathbf{F}$ & $\mathbf{M}$ & $\boldsymbol{\gamma}_{E G}$ \\
\hline 4340 Spinning and weaving* & 23 & 0.593 & 0.709 & 0.116 & 0.690 \\
2489 Ceramic goods* & 353 & 0.393 & 0.425 & 0.032 & 0.404 \\
4395 Lace* & 61 & 0.385 & 0.421 & 0.036 & 0.387 \\
2330 Extraction salt* & 5 & 0.378 & 0.431 & 0.053 & 0.519 \\
4350 Jute and polypropyle* & 27 & 0.374 & 0.437 & 0.063 & 0.427 \\
3162 Cutlery* & 64 & 0.272 & 0.358 & 0.086 & 0.287 \\
4385 Other carpets & 39 & 0.197 & 0.307 & 0.110 & 0.228 \\
4910 Jewellery* & 802 & 0.181 & 0.189 & 0.009 & 0.140 \\
4363 Hosiery* & 800 & 0.177 & 0.186 & 0.010 & 0.166 \\
3161 Handtools* & 173 & 0.174 & 0.206 & 0.032 & 0.165 \\
3634 Pedal cycles & 46 & 0.162 & 0.358 & 0.196 & 0.173 \\
4752 Periodicals & 1662 & 0.140 & 0.148 & 0.008 & 0.107 \\
4322 Weaving cotton silk* & 200 & 0.139 & 0.151 & 0.013 & 0.138 \\
3523 Caravans & 70 & 0.132 & 0.155 & 0.024 & 0.137 \\
4721 Wall coverings & 28 & 0.131 & 0.183 & 0.052 & 0.139 \\
4310 Woollen* & 402 & 0.125 & 0.132 & 0.007 & 0.131 \\
4535 Men and boys shirts & 311 & 0.116 & 0.141 & 0.025 & 0.104 \\
4240 Spirit distilling* & 93 & 0.106 & 0.142 & 0.035 & 0.107 \\
4364 Warp knitted fabrics & 60 & 0.104 & 0.138 & 0.035 & 0.096 \\
2235 Other steel forming* & 65 & 0.098 & 0.112 & 0.014 & 0.079 \\
\hline \hline
\end{tabular}

Notes: * indicates that the industry was also in the top 20 in 1985.

Measures are: $\alpha=\mathrm{F}-\mathrm{M}$ : agglomeration measure, F: geographic concentration (equation (5)), $\mathrm{M}$ : industrial concentration (equation (3)), $\gamma_{E G}$ Ellison and Glaeser (1997) agglomeration measure (equation (7)).

Table 7 shows the 20 least agglomerated industries. For these industries the measures of geographic concentration $(F)$ and industrial concentration $(M)$ are very close, thus tending to cancel each other out in the measure of agglomeration - although production is unequally distributed across regions, this is almost entirely explained by industrial concentration. The clearest example of this is Chemical treatment of oils and fats (2563) which has a very high level of geographic concentration (higher in fact than all but the most agglomerated industry in Table 6, see also Appendix C, map 6), but industrial concentration is of a similar level. This is driven by the small number of firms in the industry and the distribution of firm size.

O ther industries, such as Ready mix concrete (2436) and Builders carpentry (4630) simply have low levels of geographic concentration and low levels of industrial concentration. 
Interestingly, in our data we never observe $\alpha<0$, although this is possible - that is industrial concentration is never greater than geographic concentration.

It is striking is that a number of these industries, for example pharmaceutical products, are classified as high-tech. Attention has been drawn to the clustering of such industries, therefore we might have expected to find these industries to be geographically concentrated. Examination of the data for individual industries, for example pharmaceutical products does reveal a number of groups of firms located in what we might classify as clusters, despite the low level of geographic concentration of employment in the industry. However it may be more appropriate to investigate the existence of such clusters, for example in the Cambridge area, at a narrower industry definition than 4-digit industries.

\section{Table 7: 20 least agglomerated industries}

\begin{tabular}{lrrrrr}
\hline \hline 4-digit industry & $\begin{array}{c}\text { N umber of } \\
\text { firms }\end{array}$ & $\alpha$ & $\mathbf{F}$ & $\mathbf{M}$ & $\boldsymbol{\gamma}_{E G}$ \\
\hline 3212 Wheeled tractors & 31 & 0.005 & 0.192 & 0.187 & -0.003 \\
2420 Cement, lime, plaster & 164 & 0.005 & 0.039 & 0.034 & -0.002 \\
2563 Chemical treatment of oils & 15 & 0.004 & 0.514 & 0.511 & -0.009 \\
3262 Ball bearings & 86 & 0.004 & 0.095 & 0.090 & -0.006 \\
3453 Electronic sub-assemblies & 379 & 0.004 & 0.022 & 0.018 & 0.004 \\
2436 Ready mix concrete & 400 & 0.004 & 0.015 & 0.011 & -0.006 \\
4630 Builders carpentry & 1125 & 0.004 & 0.009 & 0.005 & 0.001 \\
2569 Adhesive film & 54 & 0.003 & 0.086 & 0.083 & -0.011 \\
1700 Water supply industry & 44 & 0.003 & 0.081 & 0.078 & -0.031 \\
4290 Tobacco industry & 23 & 0.003 & 0.072 & 0.069 & -0.011 \\
3435 Electrical equipment & 241 & 0.003 & 0.028 & 0.025 & 0.003 \\
2570 Pharmaceutical products & 368 & 0.003 & 0.019 & 0.017 & 0.003 \\
3441 Telegraph and telephone ap & 359 & 0.002 & 0.065 & 0.063 & -0.006 \\
4833 Plastic floor coverings & 29 & 0.001 & 0.100 & 0.099 & -0.009 \\
3301 Office machinery & 91 & 0.001 & 0.066 & 0.065 & 0.001 \\
2591 Photographic materials & 53 & 0.000 & 0.180 & 0.179 & 0.005 \\
2515 Synthetic rubber & 12 & 0.000 & 0.173 & 0.173 & -0.014 \\
4664 Cork and basketware & 12 & 0.000 & 0.144 & 0.144 & 0.000 \\
4200 Sugar and its by-products & 14 & 0.000 & 0.088 & 0.088 & -0.045 \\
1115 Manufacture of solid & 5 & 0.000 & 0.047 & 0.047 & -0.006 \\
\hline \hline Note: Measures are: $\alpha=F-M:$ agglomeration measure, & F: geographic concentration (equation (5)), & M: \\
industrial concentration (equation (3)), $\gamma_{\text {EG }}$ Ellison and Glaeser (1997) agglomeration measure (equation \\
(7)).
\end{tabular}

Table 17 in Appendix B shows some additional information on the top 20 agglomerated industries. Columns two and three list the two postcode areas with the highest proportion of industry employment, column four shows the total number of firms in the industry, columns five to eight show the number of firms and the proportion of employment in 
these two postcodes and columns nine and ten show the average firm size in the top postcode and in all others.

One interesting feature that can be seen from Table 17 is the difference between two types of industries - those which have single agglomeration which contains a large number of firms, and those which either have two agglomerations or which have only a few large firms in the most agglomerated region. Examples of the single agglomeration type include ceramic goods in Stoke-on-Trent, hosiery in Leicester, periodicals in London and woollens in Bradford. The second type includes jewellery which has two agglomerations, one in Birmingham and one in London, pedal cycles, which has only a small number of firms in the postcode area with the highest proportion of employment, but a larger number of firms in Birmingham accounting for only 17\% of employment, and mens and boys shirts which has an equal number of firms in Northern Ireland and Leicester, but the Northern Ireland firms account for over fives times as much employment.

In some industries the first and second postcodes are adjacent to each other and may thus indicate a larger agglomeration. Examples include ceramic goods in Stoke on Trent and D erby, lace and warp knitted fabrics in Nottingham and D erby, hosiery in Leicester and Nottingham, weaving of cotton and silk in Blackburn and Oldham, and other steel forming in Birmingham and D udley.

It is also notable that in the majority of the top 20 most agglomerated industries average firm size, as measured by the number of employees, is far higher in the agglomerated postcode than in the other postcodes. This is most likely due to the presence of at least a few large firms in the $1^{\text {st }}$ postcode area (e.g. in other carpets), which may be indicated by a high level of industrial concentration (see $M$ in Table 6). ${ }^{18}$

\section{The dynamics of agglomeration}

One issue of interest is whether these patterns of agglomeration are changing over time. D o industries become geographically concentrated in one region and stay there, or does the degree of geographic concentration and its location change, and if so, how is this change related to industry age and characteristics? What role do entry, exit, job creation

\footnotetext{
${ }^{18} \mathrm{~A}$ high value of $\mathrm{M}$ does not necessarily imply that large firms are present in the agglomerated region.
} 
and job destruction play in reinforcing agglomerations? Unfortunately we do not have comparable data on plant locations that span a long time period. Looking at the list of the 20 most agglomerated industries it is clear that many of these agglomerations initially formed in the last century or before.

In this section we describe how agglomeration patterns have changed over a short time period 1985 - 91. We describe entry and exit rates and job creation and job destruction patterns in agglomerated and non-agglomerated industries. It should be noted that in this section we calculate entry and exit rates and job creation and destruction rates using the data at the plant level, rather than the firm level as described in section 3.1.

O ur agglomeration measure $(\alpha)$ is highly correlated over the period 1985-1992. The correlation between the 1985 values and 1992 values is 0.92 . There is a high degree of persistence in agglomerated industries (though interestingly geographic and industrial concentration as less persistent, with the 1985-1992 correlations being 0.89 and 0.78 respectively). As shown in Table 6, 13 of the top 20 most agglomerated industries were also in the top 20 in 1985. Of the other seven, only one was not in the top quartile, 3634 Pedal cycles was just above the median level of agglomeration in 1985.

While there is strong persistence in general, there are a small number of industries that change their geographic or industrial concentration, or the location of the agglomeration. Four industries move from the highest quartile based on $\alpha$ in 1985 to below the median in 1991. These are shown in Table 8. Industry 2581 (Soap and detergents) decreased in size both in terms of numbers of plants and numbers of employees, and saw an increase in industrial concentration, and subsequently a decrease in agglomeration. Industry 4336 (Throwing/texturing of Continuous filament yarn) also experienced an increase in industrial concentration and a decrease in agglomeration. This was driven by changes in the distribution of employment across plants - the number of plants and industry employment remained fairly stable over the period as there was little entry and exit. 3165 (Domestic heating/cooking appliances (non-electrical)) became less geographically concentrated. Between 1985 and 1991 there was both exit from and a decrease in employment in the three postcode areas with the highest employment in 1985. 3434 (Electrical equipment for motor vehicles) decreased in size over the period, both in terms of the number of plants and total employment. There was a fall in industrial concentration and a larger fall in geographic concentration. Birmingham, which had the highest employment in the industry in 1985, saw significant job destruction. This was due to the 
exit of plants that were replaced by smaller entrants, and to decreases in employment among surviving plants.

\section{Table 8: Industries that change agglomeration status}

\begin{tabular}{|c|c|c|c|c|c|c|c|c|}
\hline \multirow{2}{*}{ Industry } & \multicolumn{3}{|c|}{1985} & & \multicolumn{3}{|c|}{1991} & \\
\hline & Rank & $\mathrm{F}$ & $\mathrm{M}$ & Emp. & Rank & $\mathrm{F}$ & M & Emp. \\
\hline $\begin{array}{l}2581 \text { Soap and } \\
\text { detergents }\end{array}$ & 40 & 0.121 & 0.064 & 10,941 & 124 & 0.111 & 0.097 & 8,114 \\
\hline $\begin{array}{l}3165 \text { D omestic } \\
\text { heating/ cooking } \\
\text { appliances (non- } \\
\text { electrical) }\end{array}$ & 49 & 0.100 & 0.054 & 9,889 & 114 & 0.068 & 0.052 & 8,028 \\
\hline $\begin{array}{l}3434 \text { Electrical } \\
\text { equipment for motor } \\
\text { vehicles }\end{array}$ & 33 & 0.149 & 0.080 & 27,027 & 111 & 0.056 & 0.040 & 19,946 \\
\hline $\begin{array}{l}4336 \\
\text { Throwing/ texturing } \\
\text { of Continuous } \\
\text { filament yarn }\end{array}$ & 50 & 0.094 & 0.050 & 1,646 & 127 & 0.104 & 0.091 & 1,623 \\
\hline
\end{tabular}

Note: Measures are: F: geographic concentration (equation (5)), M : industrial concentration (equation (3)).

There are four industries which remain in the top quartile of agglomerated industries throughout the period, but where the region in which employment is concentrated changes. These are shown in Table 9. In three of the industries - 2235 (other steel drawing and forming), 3452 (records and tapes) and 4150 (fish processing) - the regional distribution becomes more even. Records and tapes (3452) is notable in that the number of plants in Central London almost halves over the period, falling by 40, and employment falls among those that remain, making the regional distribution more even by 1992. In 4721 (wall coverings) the concentration becomes more pronounced with Blackburn and Lancaster gaining a larger share. This is due to a fall in the number of plants and employment in the industry as a whole, but with less of a fall in these regions. 
Table 9: Industries where region shifts

\begin{tabular}{crr}
\hline \hline Industry & \% employment 1985 & \% employment 1991 \\
Region & & \\
\hline 2235 (other steel drawing and forming) & 24.9 & 15.0 \\
D udley (DY) & 25.4 & 19.3 \\
Birmingham (B) & 19.7 & 18.8 \\
3452 (records and tapes) & 43.9 & 16.8 \\
Southall (UB) & & 17.0 \\
Central London (LO) & 24.6 & 19.3 \\
4150 (fish processing) & 11.4 & 34.1 \\
D oncaster (D N) & & a \\
A berdeen (AB) & 24.9 & a \\
4721 (wall coverings) & & \\
Blackburn (BB) & & \\
Lancaster & & \\
\hline \hline
\end{tabular}

a Figures not available for data confidentiality reasons

\subsection{The role of entry and exit}

There is a large amount of theoretical and empirical work on the entry and exit process of firms. Disney, Haskel and Heden (1999) use the same data set as is used here to model the entry, exit and survival of UK manufacturing plants over the period 1974-91. Their findings suggest: entry and exit rates are positively correlated at the industry level; entrants face high exit rates in their early years (20\% exit within one year, $50 \%$ within four years); and more recent cohorts face greater risk of exiting. In this section we first look at entry, exit, survival, job creation and job destruction rates in agglomerated and nonagglomerated industries. We then ask whether entry, exit, survival, job creation, and job destruction have reinforced or reduced the extent of industry agglomeration.

We follow Disney et al and classify plants as entrants (not present in $\mathrm{t}-1$, present in $\mathrm{t}$ ), exitors (present in $t$, not present in $t+1$ ), one-year (present in $t$, not in $t-1$ or $t+1$ ), survivors (present in $t-1, t, t+1$ ). We calculate mean entry, exit, one year and survival rates for each industry for the years 1985-1991. Entry, exit, one-year, and survivor rates are defined as the number of entrants, exitors, one-years and survivors respectively, divided by the total number of plants for each year. Job creation rates for each industry-year are defined as

$$
\text { job creation rate }=\frac{\text { Employment in entrants }+ \text { Increasein no. jobs in existing plants }}{\text { Total employment }}
$$

where the increase in the number of jobs in existing plants is calculated only for plants where employment increases. Similarly job destruction rates are defined as, 
job destruction rate $=\frac{\text { Employment in exitors }+ \text { Decreasein no. jobsin existing plants }}{\text { Total employment }}$.

Annual rates are calculated by industry and then an industry average annual rate is calculated for the period 1985-1991. Table 10 and Table 11 show these annual rates for the 20 most agglomerated and 20 least agglomerated industries listed in section 3.3. There appears to be little difference in these rates between the two groups of industries. D espite the fact that the most agglomerated industries are more traditional, low-low tech industries, their entry and job creation rates are not very different from the least agglomerated industries, or than the mean rates across all industries. The only difference that arises is in the survivor rates, where the most agglomerated group have a 3 percentage points higher survivor rate (although these are not significantly different).

Table 10: 20 most agglomerated industries - mean entry, exit, one-year, survivor, job creation and job destruction rates, 1985-1991

\begin{tabular}{lrrrrrr}
\hline \hline 4-digit industry & Entrants & Exitors & One-year & Survivor & $\begin{array}{r}\text { Job } \\
\text { creation }\end{array}$ & $\begin{array}{r}\text { Job } \\
\text { destruction }\end{array}$ \\
\hline 4340 Spinning and weaving & 0.05 & 0.10 & 0 & 0.83 & 0.01 & 0.07 \\
2489 Ceramic goods & 0.10 & 0.11 & 0.04 & 0.75 & 0.04 & 0.04 \\
4395 Lace & 0.06 & 0.10 & 0.03 & 0.81 & 0.06 & 0.07 \\
2330 Extraction salt & 0 & 0.07 & 0 & 0.94 & 0.01 & 0.04 \\
4350 Jute and polypropylene & 0.06 & 0.09 & 0.02 & 0.83 & 0.04 & 0.06 \\
3162 Cutlery & 0.08 & 0.09 & 0.02 & 0.80 & 0.07 & 0.08 \\
4385 Other carpets & 0.11 & 0.14 & 0.05 & 0.71 & 0.13 & 0.07 \\
4910 Jewellery & 0.11 & 0.13 & 0.06 & 0.70 & 0.09 & 0.11 \\
4363 Hosiery & 0.11 & 0.14 & 0.06 & 0.69 & 0.04 & 0.11 \\
3161 Handtools & 0.08 & 0.12 & 0.04 & 0.75 & 0.05 & 0.10 \\
3634 Pedal cycles & 0.10 & 0.17 & 0.04 & 0.71 & 0.20 & 0.20 \\
4752 Periodicals & 0.15 & 0.16 & 0.08 & 0.61 & 0.09 & 0.12 \\
4322 Weaving cotton silk & 0.08 & 0.10 & 0.04 & 0.79 & 0.04 & 0.03 \\
3523 Caravans & 0.08 & 0.10 & 0.01 & 0.81 & 0.09 & 0.02 \\
4721 Wall coverings & 0.09 & 0.12 & 0.02 & 0.77 & 0.06 & 0.15 \\
4310 Woollen & 0.07 & 0.12 & 0.02 & 0.77 & 0.03 & 0.09 \\
4535 Men and boys shirts & 0.11 & 0.14 & 0.07 & 0.68 & 0.06 & 0.09 \\
4240 Spirit distilling & 0.05 & 0.08 & 0.02 & 0.85 & 0.07 & 0.15 \\
4364 Warp knitted fabrics & 0.05 & 0.13 & 0.01 & 0.82 & 0.04 & 0.10 \\
2235 Other steel forming & 0.09 & 0.07 & 0.03 & 0.81 & 0.11 & 0.03 \\
Mean & $\mathbf{0 . 0 8}$ & $\mathbf{0 . 1 1}$ & $\mathbf{0 . 0 3}$ & $\mathbf{0 . 7 7}$ & $\mathbf{0 . 0 7}$ & $\mathbf{0 . 0 9}$ \\
Mean all industries & $\mathbf{0 . 1 0}$ & $\mathbf{0 . 1 2}$ & $\mathbf{0 . 0 4}$ & $\mathbf{0 . 7 4}$ & $\mathbf{0 . 0 7}$ & $\mathbf{0 . 0 9}$ \\
\hline \hline
\end{tabular}




\section{Table 11: 20 least agglomerated industries - mean entry, exit, one-year, job creation, and job destruction rates, 1985-1991}

\begin{tabular}{lrrrrrr}
\hline \hline 4-digit industry & Entrants & Exitors & One-year & Survivor & $\begin{array}{r}\text { Job } \\
\text { creation }\end{array}$ & $\begin{array}{r}\text { Job } \\
\text { destruction }\end{array}$ \\
\hline 3212 Wheeled tractors & 0.07 & 0.13 & 0.03 & 0.77 & 0.02 & 0.08 \\
2420 Cement, lime, plaster & 0.11 & 0.11 & 0.05 & 0.73 & 0.02 & 0.07 \\
2563 Chemical treatment of oils & 0.09 & 0.15 & 0.05 & 0.73 & 0.04 & 0.11 \\
3262 Ball bearings & 0.11 & 0.09 & 0.02 & 0.78 & 0.04 & 0.06 \\
3453 Electronic sub-assemblies & 0.12 & 0.12 & 0.04 & 0.71 & 0.06 & 0.09 \\
2436 Ready mix concrete & 0.07 & 0.07 & 0.01 & 0.84 & 0.12 & 0.10 \\
4630 Builders carpentry & 0.12 & 0.13 & 0.04 & 0.70 & 0.08 & 0.09 \\
2569 Adhesive film & 0.15 & 0.12 & 0.09 & 0.64 & 0.13 & 0.06 \\
1700 Water supply industry & 0.10 & 0.05 & 0.08 & 0.80 & 0.22 & 0.09 \\
4290 Tobacco industry & 0.04 & 0.11 & 0.02 & 0.83 & 0.01 & 0.13 \\
3435 Electrical equipment & 0.11 & 0.12 & 0.04 & 0.72 & 0.05 & 0.11 \\
2570 Pharmaceutical products & 0.09 & 0.12 & 0.04 & 0.75 & 0.03 & 0.05 \\
3441 Telegraph and telephone & 0.18 & 0.14 & 0.10 & 0.59 & 0.04 & 0.09 \\
4833 Plastic floor coverings & 0.15 & 0.17 & 0.07 & 0.62 & 0.09 & 0.07 \\
3301 Office machinery & 0.13 & 0.15 & 0.05 & 0.66 & 0.08 & 0.12 \\
2591 Photographic materials & 0.12 & 0.13 & 0.08 & 0.68 & 0.08 & 0.05 \\
2515 Synthetic rubber & 0.06 & 0.10 & 0.02 & 0.82 & 0.01 & 0.04 \\
4664 Cork and basketware & 0.08 & 0.17 & 0.01 & 0.71 & 0.14 & 0.14 \\
4200 Sugar and its by-products & 0.02 & 0.05 & 0 & 0.95 & 0 & 0.05 \\
1115 Manufacture of solid & $\mathrm{n} / \mathrm{a}$ & $\mathrm{n} / \mathrm{a}$ & $\mathrm{n} / \mathrm{a}$ & $\mathrm{n} / \mathrm{a}$ & $\mathrm{N} / \mathrm{a}$ & $\mathrm{n} / \mathrm{a}$ \\
Mean & $\mathbf{0 . 1 0}$ & $\mathbf{0 . 1 1}$ & $\mathbf{0 . 0 4}$ & $\mathbf{0 . 7 4}$ & $\mathbf{0 . 0 7}$ & $\mathbf{0 . 0 8}$ \\
Mean all industries & $\mathbf{0 . 1 0}$ & $\mathbf{0 . 1 2}$ & $\mathbf{0 . 0 4}$ & $\mathbf{0 . 7 4}$ & $\mathbf{0 . 0 7}$ & $\mathbf{0 . 0 9}$ \\
\hline \hline
\end{tabular}

Table 12 gives information on the geographic distribution of entry for the 20 most agglomerated industries. It shows the number of entrants over the years 1986-1991, the percentage of those entrants that locate in the most agglomerated region, ${ }_{1}^{19}$ and the two measures of geographic concentration (F) and agglomeration, $(\alpha)$ calculated only over entrants. Entry to many of the most agglomerated industries is also geographically concentrated. In these cases entry is also concentrated in the most agglomerated regions (the top postcode area ${ }^{20}$ ). For example, 4340 (spinning and weaving) and 3162 (cutlery) show both high geographic concentration and agglomeration among entrants and over $50 \%$ of entrants locating in the agglomerated region. On the other hand, in industries like 4535 (men and boys shirts) entry is acting against agglomeration, with only $6 \%$ of entrants going into the largest postcode areas. 
Table 12: 20 most agglomerated industries - geographic distribution of entry

\begin{tabular}{lrrrr}
\hline \hline 4-digit industry & $\begin{array}{r}\text { No. } \\
\text { entrants }\end{array}$ & $\begin{array}{r}\text { \% entrants to the top } \\
\text { postcode area }\end{array}$ & F entrants & $\alpha$ entrants \\
\hline 4340 Spinning and weaving & 11 & 64 & 0.760 & 0.501 \\
2489 Ceramic goods & 268 & 33 & 0.144 & 0.133 \\
4395 Lace & 32 & 66 & 0.311 & 0.214 \\
2330 Extraction salt & 0 & - & - & - \\
4350 Jute and polypropylene & 14 & 29 & 0.436 & 0.280 \\
3162 Cutlery & 40 & 53 & 0.447 & 0.413 \\
4385 Other carpets & 30 & $\mathrm{a}$ & 0.072 & 0.035 \\
4910 Jewellery & 652 & 17 & 0.148 & 0.143 \\
4363 Hosiery & 729 & 34 & 0.150 & 0.138 \\
3161 Handtools & 118 & 23 & 0.192 & 0.167 \\
3634 Pedal cycles & 24 & $\mathrm{a}$ & 0.428 & 0.018 \\
4752 Periodicals & 1599 & 38 & 0.142 & 0.138 \\
4322 Weaving cotton silk & 118 & 13 & 0.145 & 0.107 \\
3523 Caravans & 34 & 15 & 0.148 & 0.011 \\
4721 Wall coverings & 22 & 18 & 0.253 & 0.026 \\
4310 Woollen & 244 & 20 & 0.135 & 0.108 \\
4535 Men and boys shirts & 258 & 6 & 0.074 & 0.033 \\
4240 Spirit distilling & 53 & 21 & 0.129 & 0.081 \\
4364 Warp knitted fabrics & 23 & 35 & 0.157 & 0.083 \\
2235 Other steel forming & 32 & 19 & 0.157 & 0.087 \\
\hline \hline
\end{tabular}

a Figure not available for data confidentiality reasons

To compare industries more generally and in more detail, we calculate the proportion of entrants in each region, out of all entrants in that industry-year, and the equivalent proportion for exitors and survivors. For job creation (destruction) we calculate the proportion of jobs created (destroyed) in each region, out of all jobs created (destroyed) in that industry-year.

We then calculate a relative measure for entrants, exitors and survivors defined as the ratio of the proportion above to the proportion of plants in that industry in that region. We also calculate an equivalent relative measure for job creation and job destruction defined as the ratio of the proportion above to the proportion of industry employment in that region. If entrants, exitors, survivors and job creation and destruction were distributed across regions in just the same way that plants and employees were, then these ratios would take a value of unity.

Pictorial examples of components of these relative measures are shown for a single industry (the ceramic goods industry (2489)) in maps 7-10 in Appendix C. The geographic distributions shown are the average for the period 1985-1991. Map 7 shows the distribution of industry employment, (shown by the shaded areas), and the distribution of job creation, (shown by the overlaid dots, each representing $1 \%$ of total job creation). Map 8 the distribution of industry employment, and the distribution of job destruction. 
Map 9 the distribution of plants in the industry, and the distribution of entrants, and Map 10 the distribution of plants in the industry, and the distribution of exitors. Comparing the maps we can see that entry and exit are more geographically dispersed than job creation and destruction which are concentrated around the agglomerated region. It is interesting to note that the significant amount of entry and exit in the London area does not play a role in job creation or destruction. Job creation and destruction appear to follow a similar geographic pattern, pointing to little change in the extent and location of agglomeration in the industry.

We regress the relative measures against an indicator that equals one for the region in each industry that has the highest proportion of industry employment, (the agglomeration) and a full set of industry dummies. The coefficient on this indicator will capture differences in exit, entry, job creation or destruction rates between agglomerations and nonagglomerations within an industry. We then interact the indicator with our measure of agglomeration, capturing whether differences between regions are greater in more agglomerated industries.

The results of these regressions, reported in Table 13, show that relative exit and entry rates are lower in agglomerated regions and even more so in industries that are agglomerated. Relative job creation rates are higher in agglomerated regions, but not in more agglomerated industries. Job destruction is lower in agglomerated regions, but not in more agglomerated industries. Thus we see that agglomerated region are on the whole more static than less agglomerated regions. Exit rates are reinforcing agglomeration while entry rates are pushing in the opposite direction. Job creation rates are acting in favour of agglomeration, though not in the most agglomerated industries, while job destruction rates are working against agglomerations, though again, not in the most agglomerated industries. 
Table 13: Differences between regions

\begin{tabular}{lcccc}
\hline \hline & Relative exit rate & Relative entry rate & $\begin{array}{c}\text { Relative job } \\
\text { creation rate }\end{array}$ & $\begin{array}{c}\text { Relative job } \\
\text { destruction rate }\end{array}$ \\
\hline Indicator a & -1.32 & -1.61 & 0.292 & 0.294 \\
& 0.06 & 0.09 & 0.010 & 0.011 \\
Indicator interacted with & -7.64 & -10.95 & -0.549 & -0.799 \\
agglomeration $(\alpha)$ & & & & \\
& 0.91 & 1.72 & 0.120 & 0.208 \\
Time dummies & Yes & Yes & yes & Yes \\
4-digit industry dummies & Yes & Yes & yes & Yes \\
\hline \hline
\end{tabular}

a indictor of region with highest proportion employment

Note: Sample is of 210 industries over 1986-1990. Numbers in italics are robust standard errors.

\section{Intemational comparisons}

Empirical investigations into the extent of agglomeration have also been carried out using US and French data. Looking at 2-digit industry groups, Ellison and Glaeser (1997) use a US state-industry employment dataset. This means that the US measure is based on a more aggregated regional unit (a State) than our calculations for the UK (which are based on postcodes). Table 14 shows which of the 20 most agglomerated industries in the UK were also found to be agglomerated in the US and French studies (based on $\gamma_{E G}$ which is the only measure presented in all three studies). Four of these industries were also identified by Ellison and Glaeser (1998) as being amongst the 15 most agglomerated 4digit industries in the US. 
Table 14: Comparison of $\gamma_{E G}, \gamma_{M S}$ for UK top 20 agglomerated industries

\begin{tabular}{|c|c|c|c|c|c|c|}
\hline \multirow[t]{2}{*}{ 4-digit industry } & \multicolumn{2}{|c|}{ UK } & \multicolumn{2}{|l|}{ US } & \multicolumn{2}{|l|}{ France } \\
\hline & $\gamma_{E G}$ & rank & $\gamma_{E G}$ & Rank & $\gamma_{M S}$ & rank \\
\hline 4340 Spinning and weaving & 0.690 & 1 & & & & \\
\hline 2330 Extraction salt & 0.519 & 2 & & & & \\
\hline 4350 Jute and polypropylen & 0.427 & 3 & & & & \\
\hline 2489 Ceramic goods & 0.404 & 4 & & & & \\
\hline 4395 Lace & 0.387 & 5 & & & & \\
\hline 3162 Cutlery & 0.287 & 6 & & & 0.28 & 19 \\
\hline 4385 Other carpets & 0.228 & 7 & 0.38 & 6 & & \\
\hline 3634 Pedal cycles & 0.173 & 8 & & & & \\
\hline 4363 Hosiery & 0.166 & 9 & $0.44,0.40$ & 3,5 & & \\
\hline 3161 Handtools & 0.165 & 10 & & & & \\
\hline 4910 Jewellery & 0.140 & 11 & $0.32,0.30$ & 8,10 & & \\
\hline 4721 Wall coverings & 0.139 & 12 & & & & \\
\hline 4322 Weaving cotton silk & 0.138 & 13 & & & & \\
\hline 3523 Caravans & 0.137 & 14 & & & & \\
\hline 4310 Woollen & 0.131 & 15 & & & $0.44,0.42,0.25$ & $7,9,20$ \\
\hline 4240 Spirit distilling & 0.107 & 16 & 0.48 & 2 & & \\
\hline 4752 Periodicals & 0.107 & 17 & & & 0.40 & 10 \\
\hline 4535 Men and boys shirts & 0.104 & 18 & & & & \\
\hline 4831 Plastic coated textiles & 0.102 & 19 & & & & \\
\hline 4364 Warp knitted fabrics & 0.096 & 20 & & & & \\
\hline
\end{tabular}

Note: industry mapping between UK and US industry codes are not exact. The ones used are: UK 4240 (spirit distilling) matches US 2084 (Wines brandy, brandy spirits); UK 4363 (Hosiery) matches US 2252 (Hosiery not elsewhere classified) and 2251 (Women's hosiery); UK 4385 (O ther carpets) matches US 2273 (Carpets and rugs); UK 4910 (Jewellery) matches US 3961 (Costume jewellery) and 3915 (Jewellers' materials lapidary). Industry mapping between UK and France industry codes are: UK 3162 (Cutlery) matches France (Cutlery); UK 4310 (Woollen) matches France (Combed wool spinning mills), (Wool preparation), (Carded wool weaving mills); UK 4752 (Periodicals) matches France (Periodicals).

Maurel and Sedillot (1999) using French data at the 4-digit level find the most localised industries to be extractive industries, suggesting the importance of access to natural resources in firms' location decisions. They also find industries such as cotton and wool mills, and cutlery to be agglomerated. In addition, at the 2-digit level some hightechnology industries such as pharmaceutical goods and radio and television communication equipment are found to be geographically concentrated. 
Table 15: Comparison of $\gamma_{E G}$ for US top 20 agglomerated industries

\begin{tabular}{lll|lll}
\hline \hline US & $\gamma_{E G}$ & Rank & UK & $\gamma_{E G}$ & Rank \\
\hline \hline 2371 Fur goods & 0.63 & 1 & 4560 Fur goods & $\mathrm{n} / \mathrm{a}$ & \\
2084 Wines brandy brandy spirits & 0.48 & 2 & 4240 Spirit distilling & 0.107 & 16 \\
2252 Hosiery not elsewhere & 0.44 & 3 & 4363 Hosiery & 0.166 & 9 \\
classified & & & & & \\
3533 Oil and gas field machinery & 0.43 & 4 & 3254 Construction equipment & 0.012 & 89 \\
2251 Women's hosiery & 0.40 & 5 & 4363 Hosiery & 0.166 & 9 \\
2273 Carpets and rugs & 0.38 & 6 & 4384 Pile carpets 4385 Other & 0.068, & 26,7 \\
& & & carpets & 0.228 & \\
2429 Special product sawmills not & 0.37 & 7 & 4610 Sawmilling & 0.004 & 150 \\
elsewhere classified & & & & & \\
3961 Costume jewelry & 0.32 & 8 & 4910 Jewellery & 0.140 & 11 \\
2895 Carbon black & 0.30 & 9 & 2516 D yestuff and pigments & 0.032 & 49 \\
3915 Jewelers' materials lapidary & 0.30 & 10 & 4910 Jewellery & 0.140 & 11 \\
2874 Phosphatic fertilizers & 0.29 & 11 & 2513 Fertilisers & 0.011 & 99 \\
2061 Raw cane sugar & 0.29 & 12 & 4200 Sugar & -0.045 & 213 \\
2281 Yarn mills except wool & 0.28 & 13 & 4340 Spinning and weaving & 0.690 & 1 \\
2034 Dehydrated fruits vegetable & 0.28 & 14 & 4147 Fruit and vegetables 4239 & 0.036 & 43 \\
soups & & & Misc. foods (inc. soup) & & \\
3761 G uided missiles space vehicles & 0.25 & 15 & 3640 Aerospace equipment & 0.011 & 94 \\
\hline \hline
\end{tabular}

Note: industry mapping between UK and US industry codes are not exact.

Table 15 shows how the corresponding UK industries compare with the 15 most agglomerated US industries. ${ }^{21}$ Six of these are also amongst the 15 most agglomerated UK 4-digit industries. Those that are not will in part be due to the very different nature of the industries. For example, the UK does not have a raw cane sugar industry - the closest match is the sugar industry, which mainly consists of processing. However, other industries where there seems to be a much closer match have very different rankings. Table 16 shows the same comparison with the French top 20 agglomerated industries, based on the $\gamma_{M S}$ measure. Here there is a slightly lower correspondence, with only four of the French industries ranking in the top 20 within the UK

${ }^{21}$ Note that the industry matchings are only approximate. 
Table 16: Comparison of $\gamma_{M S}$ for French top 20 agglomerated industries

\begin{tabular}{|c|c|c|c|c|c|}
\hline France & $\gamma_{M S}$ & Rank & UK & $\gamma_{M S}$ & Rank \\
\hline Extraction of slate & 0.88 & 1 & 2310 Extraction of stone, clay & 0.005 & 101 \\
\hline Extraction of iron ore & 0.88 & 2 & $\begin{array}{l}2100 \text { Extraction and preparation } \\
\text { of metalliferous ores }\end{array}$ & $\mathrm{n} / \mathrm{a}$ & \\
\hline Made-to-measure clothing & 0.80 & 3 & $\begin{array}{l}4532 \text { Men's and boy's tailored } \\
\text { outerwear } 4533 \text { Women's and } \\
\text { girl's tailored outerwear }\end{array}$ & $\begin{array}{l}0.004, \\
0.027\end{array}$ & $\begin{array}{l}113, \\
57\end{array}$ \\
\hline $\begin{array}{l}\text { Extraction of minerals for chemical } \\
\text { industry and fertilisers }\end{array}$ & 0.76 & 4 & $\begin{array}{l}\text { 2396 Extraction of other minerals } \\
\text { n.e.s. }\end{array}$ & 0.031 & 47 \\
\hline Steel pipes and tubes & 0.69 & 5 & 2220 Steel tubes & 0.028 & 52 \\
\hline Extraction of coal & 0.53 & 6 & 1113 D eep coal mines & 0.020 & 70 \\
\hline Combed wool spinning mills & 0.44 & 7 & $\begin{array}{l}4310 \text { Woollen and worsted } \\
\text { industry }\end{array}$ & 0.118 & 17 \\
\hline Vehicles hauled by animals & 0.42 & 8 & 3650 Other vehicles & -0.003 & 174 \\
\hline Wool preparation & 0.42 & 9 & $\begin{array}{l}4310 \text { Woollen and worsted } \\
\text { industry }\end{array}$ & 0.118 & 17 \\
\hline Periodicals & 0.40 & 10 & 4752 Periodicals & 0.136 & 13 \\
\hline Watch-making & 0.38 & 11 & 3740 Clocks, watches & -0.008 & 198 \\
\hline Flat glass & 0.37 & 12 & 2471Flat glass & 0.002 & 121 \\
\hline Screw cutting & 0.36 & 13 & 3137 Bolts, nuts, etc. & 0.080 & 24 \\
\hline Lawn and garden equipment & 0.36 & 14 & $\begin{array}{l}3286 \text { O ther industrial and } \\
\text { commercial machinery }\end{array}$ & -0.003 & 171 \\
\hline Carded wool weaving mills & 0.34 & 15 & $\begin{array}{l}4310 \text { Woollen and worsted } \\
\text { industry }\end{array}$ & 0.118 & 17 \\
\hline
\end{tabular}

Other studies have used the Gini coefficient measure to examine the extent of agglomeration. Krugman (1991) uses US data, and Amiti (1998) examines the geographic concentration of industries in the EU. Following Krugman she uses a locational Gini coefficient for each industry measured relative to the geographic distribution of manufacturing. Using data for the year 1990, she finds geographic concentration within the EU to be highest in the following industries: pottery, china and earthenware, leather products, footwear, misc. petroleum and coal products, tobacco, printing and publishing, and textiles.

\section{Conclusions}

This paper has investigated the geographic concentration of production industries in the UK at a very disaggregated level both by industrial classification and regional unit of analysis. It has drawn on earlier work to develop a simple and intuitive measure of geographic concentration and agglomeration - defined as being the "excess" of geographic concentration over that which would be expected given the industrial concentration of the industry. This measure of agglomeration is simply the difference between measures of 
geographic concentration and industrial concentration and thus can easily be decomposed into these factors. It is closely related to other measures used in the literature.

We apply this measure to examine the pattern of production activity in the UK. As in the US and France we find a significant degree of geographic concentration in some industries. In some cases (such as chemical treatment of oils and fats) a very high measure of geographic concentration can be almost entirely explained by an equally high industrial concentration. However, in other cases such as ceramics, a high measure of geographic concentration is associated with a low industrial concentration. Although comparisons across countries are problematic due to differences in industry definitions and datasets, we find a number of similarities in the pattern of agglomeration between the UK, the US and France. Those industries that are most agglomerated appear to be the older and relatively low-tech industries.

We find that these patterns have remained fairly stable over the period 1985 to 1991. Analysis of entry, exit, job creation and job destruction rates finds little difference between the most and least agglomerated groups of industries. Within industries we find that exit rates are acting to re-enforce agglomeration, while entry rates are acting in the opposite direction. Job creation rates are found to re-enforce agglomeration and job destruction rates to act against, although in both cases, not in the most agglomerated industries.

The next step in this research is to identify characteristics of industries that are highly agglomerated. In particular, we wish to examine whether reasons put forward in the literature for some industries being highly agglomerated are consistent with UK evidence. We also wish to examine in more detail the extent to which industries, in particular those that have vertical linkages, are coagglomerated. 


\section{Appendix A}

Table A1: Correlation between measures

\begin{tabular}{lllllll}
\hline \hline & $\begin{array}{c}\text { Number } \\
\text { firms }\end{array}$ & $\alpha$ & $\gamma_{E G}$ & $\gamma_{M S}$ & $L_{R}$ & $L_{A}$ \\
\hline$\alpha$ & -0.090 & & & & & \\
$\gamma_{E G}$ & -0.093 & 0.988 & & & & \\
$\gamma_{M S}$ & -0.077 & 0.995 & 0.994 & & & \\
$L_{R}$ & -0.660 & 0.314 & 0.301 & 0.290 & & \\
$L_{A}$ & -0.580 & 0.374 & 0.346 & 0.346 & 0.966 & \\
$\mathrm{CI}$ & -0.110 & 0.676 & 0.649 & 0.668 & 0.454 & 0.529 \\
\hline \hline
\end{tabular}

Table A2: Spearman rank correlation

\begin{tabular}{llllll}
\hline \hline & $\alpha$ & $\gamma_{E G}$ & $\gamma_{M S}$ & $L_{R}$ & $L_{A}$ \\
\hline$\gamma_{E G}$ & 0.875 & & & & \\
[reject independence?] & yes & & & \\
$\gamma_{M S}$ & 0.979 & 0.894 & & \\
[reject independence?] & yes & yes & & & \\
$L_{R}$ & 0.340 & 0.273 & 0.236 & & \\
[reject independence?] & yes & yes & yes & & \\
$L_{A}$ & 0.416 & 0.319 & 0.317 & 0.975 & \\
[reject independence?] & yes & yes & yes & yes & \\
$C$ CI & 0.630 & 0.505 & 0.583 & 0.583 & 0.638 \\
[reject independence?] & yes & yes & yes & yes & yes \\
\hline \hline
\end{tabular}

Table A3: Q uartile distribution of industries

\begin{tabular}{lrr}
\hline \hline Q uartile & Any one of six measures & All of six measures \\
\hline 1 (lowest) & 116 & 6 \\
2 & 136 & 3 \\
3 & 127 & 1 \\
4 (highest) & 97 & 19 \\
\hline \hline
\end{tabular}

Note: Six measures are: $\alpha, \gamma_{E G}, \gamma_{M S}, L_{R}, L_{A}$ and C.

\section{Table A4: Q uartile rankings}

\begin{tabular}{lrrrr}
\hline \hline \multicolumn{1}{c}{ Industrial concentration (M) } & 1 & 2 & 3 & 4 \\
\hline G eographic concentration (F) & & & & 0 \\
1 & 36 & 17 & 17 & 0 \\
2 & 10 & 27 & 25 & 18 \\
3 & 4 & 7 & 12 & 35 \\
4 & 4 & 2 & \\
\hline \hline
\end{tabular}





\section{Appendix B}

Table 17 shows the two most concentrated regions for the 20 most agglomerated industries.

\section{Table 17: Most agglomerated regions}

\begin{tabular}{|c|c|c|c|c|c|c|c|c|c|}
\hline \multirow[t]{2}{*}{ 4-digit industry } & \multirow[t]{2}{*}{$1^{\text {st }}$ postcode } & \multirow[t]{2}{*}{$2^{\text {nd }}$ postcode } & \multirow{2}{*}{$\begin{array}{l}\text { Total } \\
\text { number } \\
\text { firms }\end{array}$} & \multicolumn{2}{|c|}{$\begin{array}{l}\text { Number firms in } \\
\text { postcode }\end{array}$} & \multicolumn{2}{|c|}{$\begin{array}{l}\text { \% employment in } \\
\text { postcode }\end{array}$} & \multicolumn{2}{|c|}{$\begin{array}{l}\text { Average firm size } \\
\text { (employment) }\end{array}$} \\
\hline & & & & $1^{\text {st }}$ & $2^{\text {nd }}$ & $1 \mathrm{st}$ & $2^{\text {nd }}$ & $1^{\text {st }}$ & Other \\
\hline 4340 Spinning and weaving & Northern Ireland & $-\mathrm{a}$ & 23 & 13 & - & 86.2 & - & 146 & - \\
\hline 2489 Ceramic goods & Stoke on Trent & D erby & 353 & 132 & 15 & 65.4 & 4.1 & 206 & 65 \\
\hline 4395 Lace & Nottingham & Derby & 61 & 36 & 9 & 63.5 & 13.6 & 53 & 44 \\
\hline 2330 Extraction salt & $-a$ & - & 5 & - & - & - & - & - & - \\
\hline 4350 Jute and polypropyle & D undee & $-a$ & 27 & 10 & - & 67.0 & - & 304 & - \\
\hline 3162 Cutlery & Sheffield & $-a$ & 64 & 42 & - & 54.6 & - & 48 & - \\
\hline 43850 ther carpets & Wakefield & $-\mathrm{a}$ & 39 & 5 & - & 54.8 & - & 276 & - \\
\hline 4910 Jewellery & Birmingham & London & 802 & 181 & 215 & 38.0 & 22.0 & 19 & 9 \\
\hline 4363 Hosiery & Leicester & Nottingham & 800 & 330 & 55 & 38.2 & 19.2 & 61 & 70 \\
\hline 3161 Handtools & Sheffield & Walsall & 173 & 47 & 6 & 44.4 & 7.9 & 68 & 32 \\
\hline 3634 Pedal cycles & $-a$ & Birmingham & 46 & - & 10 & - & 17.0 & - & 34 \\
\hline 4752 Periodicals & London & Tunbridge Wells & 1662 & 555 & 46 & 38.5 & 3.6 & 29 & 23 \\
\hline 4322 Weaving cotton silk & Blackburn & Oldham & 200 & 37 & 19 & 34.9 & 14.9 & 142 & 60 \\
\hline 3523 Caravans & Kingston upon Hull & $-\mathrm{a}$ & 70 & 15 & - & 38.4 & - & 171 & - \\
\hline 4721 Wall coverings & Blackburn & $-\mathrm{a}$ & 28 & 8 & - & 37.8 & - & 186 & - \\
\hline 4310 Woollen & Bradford & Huddersfield & 402 & 92 & 5 & 30.1 & 16.6 & 95 & 66 \\
\hline 4535 Men and boys shirts & Northern Ireland & Leicester & 311 & 32 & 34 & 36.1 & 7.1 & 222 & 45 \\
\hline 4240 Spirit distilling & G lasgow & Edinburgh & 93 & 14 & 8 & 30.8 & 12.2 & 272 & 108 \\
\hline 4364 Warp knitted fabrics & Nottingham & $-\mathrm{a}$ & 60 & 16 & - & 27.9 & - & 78 & - \\
\hline 2235 O ther steel forming & Birmingham & Dudley & 65 & 17 & 6 & 25.2 & 13.3 & 84 & 88 \\
\hline
\end{tabular}

${ }^{a}$ Figures cannot be provided for data confidentiality reasons. 
Key to table: A ll measures calculated using employment; "firm" means the aggregation of all related plants in an industry-region; measures calculated using the 113 post code areas; $\alpha=\mathrm{F}$-M, our proposed agglomeration measure; $F$ : geographic concentration (equation (5)); $M$ : industrial concentration (equation (3)); $\gamma_{M S}$ : Maurel and Sedillot (1999) measure of agglomeration (p.9); $\gamma_{E G}$ : E llison and G laeser (1997) measure of agglomeration (equation (7)); $L_{R}$ : locational $G$ ini coefficent calculate relative to total manufacturing (equation (10)); $L_{A}$ : locational $G$ ini cefficient calculate absolute (equation (10)); $C I$ : conentration index, the share of total industry employment in the top three regions.

\begin{tabular}{|c|c|c|c|c|c|c|c|c|c|c|}
\hline 4-digit industry & $\begin{array}{l}\text { Number } \\
\text { of "fims" }\end{array}$ & $\begin{array}{l}\text { Rank } \\
\text { on } \alpha\end{array}$ & $\alpha$ & $F$ & $M$ & $\gamma_{M S}$ & $\gamma_{E G}$ & $L_{R}$ & $L_{A}$ & $C I$ \\
\hline 1113 D eep coal mines & 14 & 78 & 0.023 & 0.315 & 0.292 & 0.020 & 0.034 & 0.978 & 0.972 & 0.500 \\
\hline 1115 Manufacture of solid & 5 & 209 & 0.000 & 0.047 & 0.047 & -0.017 & -0.006 & 0.970 & 0.968 & 0.600 \\
\hline 1401 Mineral oil refining & 28 & 47 & 0.042 & 0.113 & 0.072 & 0.031 & 0.044 & 0.951 & 0.943 & 0.321 \\
\hline 1402 Other treatment petr & 93 & 42 & 0.047 & 0.108 & 0.060 & 0.035 & 0.035 & 0.865 & 0.893 & 0.151 \\
\hline 1610 Production and distr & 36 & 44 & 0.044 & 0.101 & 0.057 & 0.032 & 0.001 & 0.889 & 0.905 & 0.306 \\
\hline 1700 Water supply industr & 44 & 201 & 0.003 & 0.081 & 0.078 & -0.013 & -0.031 & 0.909 & 0.899 & 0.136 \\
\hline 2210 Iron and steel & 54 & 32 & 0.065 & 0.136 & 0.072 & 0.055 & 0.058 & 0.934 & 0.943 & 0.407 \\
\hline 2220 Steel tubes & 154 & 48 & 0.041 & 0.067 & 0.026 & 0.028 & 0.025 & 0.828 & 0.857 & 0.292 \\
\hline 2234 Manufacture steel wi & 306 & 82 & 0.021 & 0.032 & 0.011 & 0.011 & 0.011 & 0.695 & 0.739 & 0.219 \\
\hline 2235 Other steel forming & 65 & 20 & 0.098 & 0.112 & 0.014 & 0.086 & 0.079 & 0.915 & 0.927 & 0.462 \\
\hline 2245 Aluminium & 256 & 90 & 0.019 & 0.038 & 0.019 & 0.009 & 0.011 & 0.786 & 0.784 & 0.180 \\
\hline 2246 Copper brass & 155 & 46 & 0.043 & 0.070 & 0.028 & 0.030 & 0.027 & 0.838 & 0.860 & 0.277 \\
\hline 2247 Other non-ferrous me & 187 & 104 & 0.017 & 0.043 & 0.026 & 0.005 & 0.007 & 0.847 & 0.813 & 0.310 \\
\hline 2310 Extraction stone cl & 252 & 105 & 0.017 & 0.026 & 0.009 & 0.005 & 0.015 & 0.676 & 0.638 & 0.147 \\
\hline 2330 Extraction salt & 5 & 4 & 0.378 & 0.431 & 0.053 & 0.498 & 0.519 & 0.988 & 0.986 & 1.000 \\
\hline 2396 Extraction other min & 113 & 50 & 0.040 & 0.190 & 0.150 & 0.031 & 0.042 & 0.888 & 0.913 & 0.204 \\
\hline 2410 Structural clay prod & 186 & 97 & 0.018 & 0.033 & 0.015 & 0.005 & 0.011 & 0.732 & 0.757 & 0.145 \\
\hline 2420 Cement lime plaste & 164 & 190 & 0.005 & 0.039 & 0.034 & -0.009 & -0.002 & 0.810 & 0.812 & 0.104 \\
\hline 2436 Ready mix concrete & 400 & 196 & 0.004 & 0.015 & 0.011 & -0.007 & -0.006 & 0.527 & 0.580 & 0.073 \\
\hline 2437 Other building produ & 665 & 150 & 0.010 & 0.014 & 0.004 & 0.001 & 0.008 & 0.523 & 0.588 & 0.138 \\
\hline 2440 Asbestos goods & 26 & 117 & 0.014 & 0.121 & 0.108 & -0.001 & 0.012 & 0.948 & 0.944 & 0.231 \\
\hline 2450 Working of stone & 1048 & 191 & 0.005 & 0.012 & 0.007 & -0.003 & 0.007 & 0.518 & 0.504 & 0.097 \\
\hline 2460 Abrasive products & 73 & 79 & 0.023 & 0.069 & 0.046 & 0.008 & 0.001 & 0.841 & 0.872 & 0.192 \\
\hline
\end{tabular}




\begin{tabular}{|c|c|c|c|c|c|c|c|c|c|c|}
\hline 4-digit industry & $\begin{array}{l}\text { Number } \\
\text { of "fims" }\end{array}$ & $\begin{array}{l}\text { Rank } \\
\text { on } \alpha\end{array}$ & $\alpha$ & $F$ & $M$ & $\gamma_{M S}$ & $\gamma_{E G}$ & $L_{R}$ & $L_{A}$ & $C I$ \\
\hline 2471 Flat glass & 210 & 118 & 0.014 & 0.056 & 0.042 & 0.002 & 0.000 & 0.764 & 0.805 & 0.162 \\
\hline 2478 G lass containers & 37 & 36 & 0.057 & 0.122 & 0.065 & 0.047 & 0.051 & 0.937 & 0.940 & 0.297 \\
\hline 2479 Other glass products & 314 & 119 & 0.014 & 0.032 & 0.018 & 0.004 & 0.009 & 0.793 & 0.756 & 0.169 \\
\hline 2481 Refractory goods & 134 & 34 & 0.061 & 0.082 & 0.020 & 0.049 & 0.050 & 0.843 & 0.869 & 0.261 \\
\hline 2489 Ceramic goods & 353 & 2 & 0.393 & 0.425 & 0.032 & 0.403 & 0.404 & 0.858 & 0.905 & 0.453 \\
\hline 2511 Inorganic chemicals & 149 & 98 & 0.018 & 0.064 & 0.046 & 0.005 & 0.013 & 0.864 & 0.863 & 0.161 \\
\hline 2512 Basic organic chemic & 150 & 68 & 0.030 & 0.111 & 0.081 & 0.020 & 0.031 & 0.887 & 0.884 & 0.113 \\
\hline 2513 Fertilisers & 93 & 134 & 0.012 & 0.178 & 0.166 & -0.002 & 0.011 & 0.889 & 0.914 & 0.215 \\
\hline 2514 Synthetic resins and & 468 & 151 & 0.010 & 0.028 & 0.018 & 0.001 & 0.004 & 0.654 & 0.688 & 0.098 \\
\hline 2515 Synthetic rubber & 12 & 210 & 0.000 & 0.173 & 0.173 & -0.017 & -0.014 & 0.968 & 0.967 & 0.250 \\
\hline 2516 D yestuff and pigment & 87 & 53 & 0.038 & 0.093 & 0.055 & 0.025 & 0.032 & 0.906 & 0.895 & 0.218 \\
\hline 2551 Paints & 274 & 135 & 0.012 & 0.035 & 0.023 & 0.001 & 0.004 & 0.784 & 0.785 & 0.146 \\
\hline 2552 Printing ink & 98 & 75 & 0.027 & 0.084 & 0.057 & 0.013 & 0.011 & 0.940 & 0.881 & 0.184 \\
\hline 2562 Formulated adhesives & 181 & 110 & 0.016 & 0.035 & 0.020 & 0.003 & 0.006 & 0.775 & 0.784 & 0.133 \\
\hline 2563 Chemical treatment 0 & 15 & 197 & 0.004 & 0.514 & 0.511 & -0.008 & -0.009 & 0.973 & 0.978 & 0.333 \\
\hline 2564 Essential oils and f & 54 & 111 & 0.016 & 0.086 & 0.070 & 0.001 & -0.003 & 0.917 & 0.911 & 0.185 \\
\hline 2565 Explosives & 31 & 174 & 0.007 & 0.120 & 0.112 & -0.008 & 0.011 & 0.946 & 0.937 & 0.226 \\
\hline 2567 Misc chemicals for i & 429 & 140 & 0.011 & 0.027 & 0.016 & 0.001 & 0.006 & 0.646 & 0.695 & 0.110 \\
\hline 2568 Formulated pesticide & 74 & 76 & 0.025 & 0.094 & 0.069 & 0.011 & 0.027 & 0.909 & 0.901 & 0.149 \\
\hline 2569 Adhesive film & 54 & 202 & 0.003 & 0.086 & 0.083 & -0.013 & -0.011 & 0.885 & 0.904 & 0.130 \\
\hline 2570 Pharmaceutical produ & 368 & 203 & 0.003 & 0.019 & 0.017 & -0.008 & 0.003 & 0.722 & 0.687 & 0.125 \\
\hline 2581 Soap & 150 & 83 & 0.021 & 0.064 & 0.043 & 0.008 & 0.009 & 0.828 & 0.862 & 0.147 \\
\hline 2582 Perfumes and cosmeti & 228 & 141 & 0.011 & 0.035 & 0.024 & 0.000 & 0.007 & 0.784 & 0.784 & 0.197 \\
\hline 2591 Photographic materia & 53 & 211 & 0.000 & 0.180 & 0.179 & -0.016 & 0.005 & 0.957 & 0.933 & 0.189 \\
\hline 2599 Other chemicals & 104 & 127 & 0.013 & 0.056 & 0.043 & -0.002 & 0.009 & 0.866 & 0.847 & 0.154 \\
\hline 2600 Production of man-ma & 30 & 40 & 0.048 & 0.113 & 0.065 & 0.037 & 0.043 & 0.929 & 0.937 & 0.300 \\
\hline 3111 Ferrous metal foundr & 403 & 71 & 0.029 & 0.037 & 0.008 & 0.020 & 0.020 & 0.697 & 0.753 & 0.228 \\
\hline 3112 Non-ferrous metal fo & 296 & 60 & 0.033 & 0.040 & 0.006 & 0.023 & 0.020 & 0.741 & 0.752 & 0.247 \\
\hline 3120 Forging pressing & 960 & 27 & 0.069 & 0.073 & 0.004 & 0.062 & 0.055 & 0.631 & 0.733 & 0.264 \\
\hline 3137 Bolts nuts etc. & 567 & 23 & 0.088 & 0.096 & 0.008 & 0.080 & 0.070 & 0.710 & 0.794 & 0.353 \\
\hline
\end{tabular}




\begin{tabular}{|c|c|c|c|c|c|c|c|c|c|c|}
\hline 4-digit industry & $\begin{array}{l}\text { Number } \\
\text { of "fims" }\end{array}$ & $\begin{array}{l}\text { Rank } \\
\text { on } \alpha\end{array}$ & $\alpha$ & $F$ & $M$ & $\gamma_{M S}$ & $\gamma_{E G}$ & $L_{R}$ & $L_{A}$ & $C I$ \\
\hline 3138 Heat and surface tre & 841 & 64 & 0.032 & 0.035 & 0.003 & 0.023 & 0.020 & 0.540 & 0.655 & 0.213 \\
\hline 3142 Metal doors & 509 & 120 & 0.014 & 0.021 & 0.007 & 0.004 & 0.008 & 0.604 & 0.639 & 0.169 \\
\hline 3161 Handtools & 173 & 10 & 0.174 & 0.206 & 0.032 & 0.170 & 0.165 & 0.859 & 0.886 & 0.387 \\
\hline 3162 Cutlery & 64 & 6 & 0.272 & 0.358 & 0.086 & 0.291 & 0.287 & 0.975 & 0.974 & 0.781 \\
\hline 3163 Metal storage vessel & 87 & 84 & 0.021 & 0.048 & 0.027 & 0.005 & 0.006 & 0.829 & 0.832 & 0.241 \\
\hline 3164 Packaging products 0 & 290 & 136 & 0.012 & 0.022 & 0.010 & 0.001 & 0.005 & 0.664 & 0.693 & 0.172 \\
\hline 3165 D omestic heating app & 83 & 91 & 0.019 & 0.071 & 0.052 & 0.004 & 0.004 & 0.898 & 0.894 & 0.229 \\
\hline 3166 Metal furniture & 355 & 152 & 0.010 & 0.020 & 0.010 & 0.000 & 0.004 & 0.694 & 0.690 & 0.186 \\
\hline 3167 D omestic utensils of & 148 & 37 & 0.053 & 0.094 & 0.040 & 0.042 & 0.035 & 0.807 & 0.859 & 0.264 \\
\hline 3169 Other finished metal & 4104 & 87 & 0.020 & 0.021 & 0.001 & 0.012 & 0.012 & 0.378 & 0.551 & 0.179 \\
\hline 3204 Fabricated steelwork & 660 & 121 & 0.014 & 0.026 & 0.012 & 0.006 & 0.018 & 0.763 & 0.664 & 0.111 \\
\hline 3205 Boilers & 1240 & 164 & 0.008 & 0.017 & 0.009 & 0.000 & 0.006 & 0.586 & 0.618 & 0.138 \\
\hline 3211 Agricultural machine & 298 & 99 & 0.018 & 0.028 & 0.011 & 0.007 & 0.021 & 0.795 & 0.732 & 0.158 \\
\hline 3212 Wheeled tractors & 31 & 192 & 0.005 & 0.192 & 0.187 & -0.011 & -0.003 & 0.965 & 0.960 & 0.258 \\
\hline 3221 Metal-worked machine & 1091 & 80 & 0.023 & 0.028 & 0.005 & 0.015 & 0.014 & 0.588 & 0.658 & 0.215 \\
\hline 3222 Engineers small tool & 1097 & 56 & 0.037 & 0.040 & 0.003 & 0.029 & 0.027 & 0.551 & 0.665 & 0.279 \\
\hline 3230 Textile machinery & 246 & 65 & 0.032 & 0.056 & 0.024 & 0.021 & 0.026 & 0.865 & 0.862 & 0.293 \\
\hline 3244 Processing machinery & 303 & 160 & 0.009 & 0.019 & 0.010 & -0.001 & 0.007 & 0.641 & 0.640 & 0.106 \\
\hline 3245 Machinery for chemic & 402 & 142 & 0.011 & 0.020 & 0.008 & 0.001 & 0.005 & 0.647 & 0.669 & 0.142 \\
\hline 3246 Process engineering & 40 & 35 & 0.058 & 0.106 & 0.047 & 0.047 & 0.028 & 0.914 & 0.918 & 0.275 \\
\hline 3251 Mining machinery & 123 & 49 & 0.041 & 0.069 & 0.028 & 0.027 & 0.032 & 0.841 & 0.857 & 0.244 \\
\hline 3254 Construction equipme & 239 & 92 & 0.019 & 0.042 & 0.024 & 0.008 & 0.012 & 0.789 & 0.796 & 0.134 \\
\hline 3255 Lifting equipment & 1164 & 165 & 0.008 & 0.016 & 0.008 & -0.001 & 0.000 & 0.543 & 0.607 & 0.139 \\
\hline 3261 Power transmission e & 1344 & 175 & 0.007 & 0.013 & 0.006 & -0.001 & 0.006 & 0.538 & 0.573 & 0.117 \\
\hline 3262 Ball bearings & 86 & 198 & 0.004 & 0.095 & 0.090 & -0.012 & -0.006 & 0.907 & 0.906 & 0.174 \\
\hline 3275 Machinery for wood & 327 & 100 & 0.018 & 0.034 & 0.017 & 0.007 & 0.012 & 0.668 & 0.711 & 0.138 \\
\hline 3276 Machinery for printi & 222 & 69 & 0.030 & 0.061 & 0.031 & 0.019 & 0.022 & 0.795 & 0.828 & 0.221 \\
\hline 3281 Combustion engines & 244 & 93 & 0.019 & 0.068 & 0.049 & 0.009 & 0.017 & 0.837 & 0.838 & 0.115 \\
\hline 3283 Fluid power equipmen & 417 & 161 & 0.009 & 0.020 & 0.011 & -0.001 & 0.007 & 0.722 & 0.692 & 0.134 \\
\hline 3284 Refrigerating and ve & 823 & 176 & 0.007 & 0.013 & 0.006 & -0.001 & 0.003 & 0.556 & 0.584 & 0.115 \\
\hline
\end{tabular}




\begin{tabular}{|c|c|c|c|c|c|c|c|c|c|c|}
\hline 4-digit industry & $\begin{array}{l}\text { Number } \\
\text { of "fims" }\end{array}$ & $\begin{array}{l}\text { Rank } \\
\text { on } \alpha\end{array}$ & $\alpha$ & $F$ & $M$ & $\gamma_{M S}$ & $\gamma_{E G}$ & $L_{R}$ & $L_{A}$ & $C I$ \\
\hline 3285 Weighing machines & 168 & 106 & 0.017 & 0.072 & 0.056 & 0.005 & -0.008 & 0.794 & 0.825 & 0.113 \\
\hline 32860 ther industrial and & 415 & 177 & 0.007 & 0.022 & 0.015 & -0.003 & 0.003 & 0.634 & 0.665 & 0.133 \\
\hline 3287 Pumps & 272 & 143 & 0.011 & 0.032 & 0.021 & 0.000 & 0.005 & 0.689 & 0.738 & 0.096 \\
\hline 3288 Industrial valves & 217 & 115 & 0.015 & 0.034 & 0.019 & 0.003 & 0.007 & 0.780 & 0.777 & 0.129 \\
\hline 3289 Other engineering & 4188 & 182 & 0.006 & 0.008 & 0.002 & -0.002 & 0.003 & 0.386 & 0.455 & 0.123 \\
\hline 3290 O rdnance small arms & 78 & 162 & 0.009 & 0.047 & 0.038 & -0.007 & -0.002 & 0.862 & 0.857 & 0.295 \\
\hline 3301 Office machinery & 91 & 207 & 0.001 & 0.066 & 0.065 & -0.016 & 0.001 & 0.861 & 0.847 & 0.143 \\
\hline 3302 Electronic data proc & 1023 & 128 & 0.013 & 0.035 & 0.022 & 0.005 & 0.008 & 0.739 & 0.755 & 0.163 \\
\hline 3410 Insulated wires & 259 & 129 & 0.013 & 0.038 & 0.025 & 0.002 & 0.010 & 0.807 & 0.786 & 0.151 \\
\hline 3420 Basic electrical equ & 1423 & 166 & 0.008 & 0.021 & 0.013 & 0.000 & -0.001 & 0.472 & 0.633 & 0.115 \\
\hline 3432 Batteries & 137 & 81 & 0.022 & 0.059 & 0.037 & 0.008 & 0.007 & 0.852 & 0.867 & 0.146 \\
\hline 3433 Alarms and signallin & 371 & 137 & 0.012 & 0.031 & 0.020 & 0.002 & 0.004 & 0.704 & 0.733 & 0.111 \\
\hline 3434 Electrical equipment & 351 & 101 & 0.018 & 0.059 & 0.041 & 0.009 & 0.008 & 0.792 & 0.833 & 0.174 \\
\hline 3435 Electrical equipment & 241 & 204 & 0.003 & 0.028 & 0.025 & -0.009 & 0.003 & 0.778 & 0.718 & 0.145 \\
\hline 3441 Telegraph and teleph & 359 & 206 & 0.002 & 0.065 & 0.063 & -0.008 & -0.006 & 0.755 & 0.807 & 0.150 \\
\hline 3442 Electrical instrumen & 892 & 183 & 0.006 & 0.013 & 0.007 & -0.003 & 0.007 & 0.560 & 0.569 & 0.081 \\
\hline 3443 Radio and electronic & 727 & 153 & 0.010 & 0.029 & 0.019 & 0.002 & 0.014 & 0.745 & 0.751 & 0.117 \\
\hline 3444 Other components for & 779 & 193 & 0.005 & 0.011 & 0.006 & -0.004 & 0.006 & 0.563 & 0.550 & 0.105 \\
\hline 3452 Records and tapes & 107 & 38 & 0.050 & 0.111 & 0.061 & 0.038 & 0.035 & 0.929 & 0.926 & 0.495 \\
\hline 3453 Electronic sub-assem & 379 & 199 & 0.004 & 0.022 & 0.018 & -0.006 & 0.004 & 0.725 & 0.706 & 0.116 \\
\hline 3454 Other electronic con & 313 & 43 & 0.046 & 0.093 & 0.047 & 0.038 & 0.046 & 0.771 & 0.808 & 0.153 \\
\hline 3460 D omestic electric ap & 246 & 154 & 0.010 & 0.042 & 0.032 & -0.002 & 0.005 & 0.846 & 0.818 & 0.175 \\
\hline 3470 Electric lamps & 990 & 194 & 0.005 & 0.018 & 0.012 & -0.003 & 0.000 & 0.672 & 0.650 & 0.163 \\
\hline 3510 Motor vehicles and e & 189 & 39 & 0.050 & 0.104 & 0.054 & 0.041 & 0.041 & 0.875 & 0.899 & 0.143 \\
\hline 3521 Motor vehicle bodies & 229 & 155 & 0.010 & 0.028 & 0.017 & -0.001 & 0.005 & 0.720 & 0.712 & 0.135 \\
\hline 3522 Trailers & 131 & 112 & 0.016 & 0.034 & 0.018 & 0.001 & 0.009 & 0.801 & 0.787 & 0.168 \\
\hline 3523 Caravans & 70 & 14 & 0.132 & 0.155 & 0.024 & 0.122 & 0.137 & 0.914 & 0.899 & 0.329 \\
\hline 3530 Motor vehicle parts & 1084 & 102 & 0.018 & 0.024 & 0.006 & 0.010 & 0.011 & 0.597 & 0.664 & 0.141 \\
\hline 3610 Shipbuilding & 843 & 107 & 0.017 & 0.101 & 0.084 & 0.011 & 0.021 & 0.858 & 0.876 & 0.189 \\
\hline 3620 Railway and tramway & 57 & 108 & 0.017 & 0.162 & 0.145 & 0.004 & 0.006 & 0.935 & 0.935 & 0.175 \\
\hline
\end{tabular}




\begin{tabular}{|c|c|c|c|c|c|c|c|c|c|c|}
\hline 4-digit industry & $\begin{array}{l}\text { Number } \\
\text { of "fims" }\end{array}$ & $\begin{array}{l}\text { Rank } \\
\text { on } \alpha\end{array}$ & $\alpha$ & $F$ & $M$ & $\gamma_{M S}$ & $\gamma_{E G}$ & $L_{R}$ & $L_{A}$ & $C I$ \\
\hline 3633 Motor cycles & 32 & 58 & 0.035 & 0.064 & 0.029 & 0.021 & 0.016 & 0.901 & 0.901 & 0.312 \\
\hline 3634 Pedal cycles & 46 & 11 & 0.162 & 0.358 & 0.196 & 0.194 & 0.173 & 0.948 & 0.965 & 0.370 \\
\hline 3640 Aerospace equipment & 543 & 144 & 0.011 & 0.033 & 0.022 & 0.002 & 0.011 & 0.721 & 0.751 & 0.127 \\
\hline 3650 Other vehicles & 43 & 145 & 0.011 & 0.131 & 0.120 & -0.003 & 0.003 & 0.957 & 0.933 & 0.140 \\
\hline 3710 Precision instrument & 1250 & 178 & 0.007 & 0.012 & 0.005 & -0.002 & 0.004 & 0.548 & 0.574 & 0.108 \\
\hline 3720 Medical equipment & 371 & 146 & 0.011 & 0.023 & 0.012 & 0.001 & 0.005 & 0.714 & 0.715 & 0.167 \\
\hline 3731 Spectacles & 180 & 94 & 0.019 & 0.042 & 0.022 & 0.007 & 0.006 & 0.770 & 0.777 & 0.156 \\
\hline 3732 Optical instruments & 100 & 61 & 0.033 & 0.134 & 0.101 & 0.021 & 0.032 & 0.890 & 0.898 & 0.160 \\
\hline 3733 Photographic euipmen & 91 & 167 & 0.008 & 0.108 & 0.100 & -0.008 & 0.003 & 0.901 & 0.902 & 0.220 \\
\hline 3740 Clocks and timing de & 116 & 168 & 0.008 & 0.049 & 0.042 & -0.008 & -0.005 & 0.849 & 0.831 & 0.172 \\
\hline 4115 Margarine and cookin & 12 & 26 & 0.078 & 0.149 & 0.071 & 0.077 & 0.090 & 0.972 & 0.963 & 0.500 \\
\hline 4116 Oil processing & 31 & 28 & 0.069 & 0.118 & 0.049 & 0.059 & 0.044 & 0.945 & 0.940 & 0.290 \\
\hline 4121 Slaughterhouses & 247 & 130 & 0.013 & 0.021 & 0.008 & 0.001 & 0.010 & 0.706 & 0.689 & 0.117 \\
\hline 4122 Bacon curing & 474 & 195 & 0.005 & 0.016 & 0.011 & -0.004 & 0.002 & 0.598 & 0.634 & 0.154 \\
\hline 4123 Poultry slaughter & 127 & 77 & 0.024 & 0.047 & 0.022 & 0.010 & 0.021 & 0.854 & 0.824 & 0.181 \\
\hline 4126 Animal by-products & 65 & 95 & 0.019 & 0.049 & 0.030 & 0.003 & 0.005 & 0.856 & 0.850 & 0.215 \\
\hline 4130 Milk products & 258 & 169 & 0.008 & 0.019 & 0.011 & -0.003 & 0.002 & 0.681 & 0.665 & 0.182 \\
\hline 4147 Fruit and vegetables & 189 & 52 & 0.039 & 0.055 & 0.017 & 0.027 & 0.036 & 0.809 & 0.813 & 0.190 \\
\hline 4150 Fish processing & 198 & 29 & 0.068 & 0.119 & 0.052 & 0.060 & 0.074 & 0.921 & 0.895 & 0.333 \\
\hline $4160 \mathrm{G}$ rain milling & 115 & 109 & 0.017 & 0.024 & 0.008 & 0.001 & 0.005 & 0.753 & 0.751 & 0.165 \\
\hline 4180 Starch & 9 & 41 & 0.048 & 0.203 & 0.154 & 0.050 & 0.016 & 0.972 & 0.973 & 0.556 \\
\hline 4196 Bread and flour conf & 989 & 184 & 0.006 & 0.011 & 0.005 & -0.003 & 0.001 & 0.519 & 0.546 & 0.164 \\
\hline 4197 Biscuits and crispbr & 65 & 96 & 0.019 & 0.056 & 0.037 & 0.004 & 0.000 & 0.877 & 0.884 & 0.215 \\
\hline 4200 Sugar and its by-pro & 14 & 212 & 0.000 & 0.088 & 0.088 & -0.017 & -0.045 & 0.929 & 0.938 & 0.214 \\
\hline 4213 Ice cream & 116 & 185 & 0.006 & 0.095 & 0.090 & -0.010 & 0.000 & 0.879 & 0.886 & 0.164 \\
\hline 4214 Chocolate & 191 & 138 & 0.012 & 0.058 & 0.047 & 0.000 & 0.000 & 0.799 & 0.821 & 0.147 \\
\hline 4221 Compound animal feed & 285 & 131 & 0.013 & 0.020 & 0.007 & 0.002 & 0.015 & 0.741 & 0.692 & 0.140 \\
\hline 4222 Pet foods & 153 & 156 & 0.010 & 0.047 & 0.037 & -0.004 & 0.000 & 0.777 & 0.801 & 0.255 \\
\hline 4239 Misc. foods & 657 & 170 & 0.008 & 0.020 & 0.012 & -0.001 & 0.004 & 0.677 & 0.683 & 0.148 \\
\hline 4240 Spirit distilling & 93 & 18 & 0.106 & 0.142 & 0.035 & 0.097 & 0.107 & 0.923 & 0.936 & 0.398 \\
\hline
\end{tabular}




\begin{tabular}{|c|c|c|c|c|c|c|c|c|c|c|}
\hline 4-digit industry & $\begin{array}{l}\text { Number } \\
\text { of "fims" }\end{array}$ & $\begin{array}{l}\text { Rank } \\
\text { on } \alpha\end{array}$ & $\alpha$ & $F$ & $M$ & $\gamma_{M S}$ & $\gamma_{E G}$ & $L_{R}$ & $L_{A}$ & $C I$ \\
\hline 4261 Wines cider and per & 31 & 122 & 0.014 & 0.181 & 0.167 & 0.001 & 0.025 & 0.970 & 0.955 & 0.258 \\
\hline 4270 Brewing and malting & 175 & 85 & 0.021 & 0.039 & 0.018 & 0.008 & 0.007 & 0.770 & 0.770 & 0.131 \\
\hline 4283 Soft drinks & 166 & 147 & 0.011 & 0.027 & 0.017 & -0.003 & 0.004 & 0.785 & 0.759 & 0.139 \\
\hline 4290 Tobacco industry & 23 & 205 & 0.003 & 0.072 & 0.069 & -0.013 & -0.011 & 0.935 & 0.930 & 0.261 \\
\hline 4310 Woollen & 402 & 16 & 0.125 & 0.132 & 0.007 & 0.118 & 0.131 & 0.889 & 0.902 & 0.500 \\
\hline 4321 Spinning cotton & 70 & 45 & 0.044 & 0.069 & 0.024 & 0.030 & 0.035 & 0.869 & 0.884 & 0.357 \\
\hline 4322 Weaving cotton silk & 200 & 13 & 0.139 & 0.151 & 0.013 & 0.131 & 0.138 & 0.884 & 0.897 & 0.375 \\
\hline 4336 Continuous filament & 23 & 157 & 0.010 & 0.087 & 0.077 & -0.005 & -0.003 & 0.925 & 0.934 & 0.391 \\
\hline 4340 Spinning and weaving & 23 & 1 & 0.593 & 0.709 & 0.116 & 0.701 & 0.690 & 0.981 & 0.987 & 0.696 \\
\hline 4350 Jute and polypropyle & 27 & 5 & 0.374 & 0.437 & 0.063 & 0.406 & 0.427 & 0.980 & 0.976 & 0.556 \\
\hline 4363 Hosiery & 800 & 9 & 0.177 & 0.186 & 0.010 & 0.173 & 0.166 & 0.883 & 0.907 & 0.559 \\
\hline 4364 Warp knitted fabrics & 60 & 19 & 0.104 & 0.138 & 0.035 & 0.094 & 0.096 & 0.932 & 0.938 & 0.617 \\
\hline 4370 Textiles finishing & 417 & 62 & 0.033 & 0.039 & 0.005 & 0.024 & 0.030 & 0.792 & 0.808 & 0.273 \\
\hline 4384 Pile carpets & 180 & 30 & 0.067 & 0.089 & 0.022 & 0.057 & 0.068 & 0.855 & 0.868 & 0.233 \\
\hline 4385 Other carpets & 39 & 7 & 0.197 & 0.307 & 0.110 & 0.215 & 0.228 & 0.961 & 0.962 & 0.282 \\
\hline 4395 Lace & 61 & 3 & 0.385 & 0.421 & 0.036 & 0.396 & 0.387 & 0.969 & 0.976 & 0.836 \\
\hline 4396 Rope & 78 & 70 & 0.030 & 0.071 & 0.041 & 0.016 & 0.020 & 0.942 & 0.871 & 0.192 \\
\hline 4398 Narrow fabrics & 126 & 25 & 0.079 & 0.093 & 0.014 & 0.066 & 0.064 & 0.866 & 0.895 & 0.373 \\
\hline 4399 O ther misc. textiles & 328 & 54 & 0.038 & 0.073 & 0.036 & 0.029 & 0.042 & 0.872 & 0.844 & 0.220 \\
\hline 4410 Leather tanning & 156 & 57 & 0.036 & 0.059 & 0.023 & 0.023 & 0.025 & 0.812 & 0.831 & 0.333 \\
\hline 4420 Leather goods & 416 & 33 & 0.064 & 0.070 & 0.006 & 0.055 & 0.048 & 0.769 & 0.822 & 0.483 \\
\hline 4510 Footwear & 380 & 31 & 0.067 & 0.081 & 0.015 & 0.059 & 0.063 & 0.839 & 0.853 & 0.529 \\
\hline 4531 Weatherproof & 201 & 72 & 0.029 & 0.043 & 0.013 & 0.018 & 0.019 & 0.766 & 0.796 & 0.259 \\
\hline 4532 Men and boys tailore & 423 & 132 & 0.013 & 0.028 & 0.015 & 0.004 & 0.007 & 0.781 & 0.754 & 0.364 \\
\hline 4533 Women and girls tail & 666 & 59 & 0.035 & 0.054 & 0.019 & 0.027 & 0.015 & 0.790 & 0.816 & 0.691 \\
\hline 4534 Work clothing for me & 214 & 123 & 0.014 & 0.029 & 0.015 & 0.002 & 0.006 & 0.780 & 0.763 & 0.332 \\
\hline 4535 Men and boys shirts & 311 & 17 & 0.116 & 0.141 & 0.025 & 0.110 & 0.104 & 0.787 & 0.844 & 0.379 \\
\hline 4536 Womens and girls wea & 1822 & 73 & 0.029 & 0.035 & 0.006 & 0.021 & 0.009 & 0.618 & 0.715 & 0.639 \\
\hline 4537 Hats & 71 & 24 & 0.084 & 0.109 & 0.025 & 0.072 & 0.070 & 0.928 & 0.913 & 0.549 \\
\hline 4538 Gloves & 54 & 51 & 0.040 & 0.109 & 0.068 & 0.028 & 0.037 & 0.940 & 0.915 & 0.426 \\
\hline
\end{tabular}




\begin{tabular}{|c|c|c|c|c|c|c|c|c|c|c|}
\hline 4-digit industry & $\begin{array}{l}\text { Number } \\
\text { of "fims" }\end{array}$ & $\begin{array}{l}\text { Rank } \\
\text { on } \alpha\end{array}$ & $\alpha$ & $F$ & $M$ & $\gamma_{M S}$ & $\gamma_{E G}$ & $L_{R}$ & $L_{A}$ & $C I$ \\
\hline 4539 0 ther dress industri & 448 & 63 & 0.033 & 0.050 & 0.017 & 0.025 & 0.016 & 0.751 & 0.796 & 0.536 \\
\hline 4555 Soft furnishings & 225 & 67 & 0.031 & 0.048 & 0.017 & 0.020 & 0.022 & 0.823 & 0.826 & 0.240 \\
\hline 4556 Canvas goods & 336 & 124 & 0.014 & 0.023 & 0.009 & 0.003 & 0.006 & 0.661 & 0.698 & 0.152 \\
\hline 4557 Household textiles & 268 & 55 & 0.038 & 0.057 & 0.019 & 0.028 & 0.031 & 0.823 & 0.846 & 0.231 \\
\hline 4610 Sawmilling & 728 & 186 & 0.006 & 0.010 & 0.004 & -0.003 & 0.004 & 0.596 & 0.522 & 0.104 \\
\hline 4620 Semi-finished wood & 152 & 125 & 0.014 & 0.042 & 0.028 & 0.000 & 0.002 & 0.817 & 0.797 & 0.164 \\
\hline 4630 Builders carpentry & 1125 & 200 & 0.004 & 0.009 & 0.005 & -0.005 & 0.001 & 0.478 & 0.509 & 0.148 \\
\hline 4640 Wood containers & 477 & 187 & 0.006 & 0.012 & 0.006 & -0.004 & 0.003 & 0.596 & 0.594 & 0.130 \\
\hline 4650 O ther wooden article & 511 & 139 & 0.012 & 0.018 & 0.005 & 0.003 & 0.000 & 0.559 & 0.635 & 0.162 \\
\hline 4663 Brushes and brooms & 97 & 113 & 0.016 & 0.049 & 0.032 & 0.001 & -0.001 & 0.842 & 0.834 & 0.216 \\
\hline 4664 Cork and basketware & 12 & 213 & 0.000 & 0.144 & 0.144 & -0.017 & 0.000 & 0.961 & 0.951 & 0.250 \\
\hline 4671 Wood furniture & 2422 & 158 & 0.010 & 0.013 & 0.003 & 0.002 & 0.004 & 0.468 & 0.573 & 0.164 \\
\hline 4672 Shop and office fitt & 866 & 116 & 0.015 & 0.018 & 0.003 & 0.007 & 0.003 & 0.513 & 0.591 & 0.206 \\
\hline 4710 Pulp and paper & 307 & 86 & 0.021 & 0.030 & 0.009 & 0.010 & 0.022 & 0.744 & 0.731 & 0.134 \\
\hline 4721 Wall coverings & 28 & 15 & 0.131 & 0.183 & 0.052 & 0.129 & 0.139 & 0.955 & 0.954 & 0.500 \\
\hline 4722 Household paper prod & 105 & 114 & 0.016 & 0.047 & 0.030 & 0.001 & 0.001 & 0.859 & 0.848 & 0.124 \\
\hline 4723 Stationery & 726 & 133 & 0.013 & 0.020 & 0.007 & 0.004 & 0.004 & 0.631 & 0.638 & 0.202 \\
\hline 4724 Paper and pulp packa & 247 & 171 & 0.008 & 0.022 & 0.014 & -0.004 & 0.003 & 0.712 & 0.703 & 0.121 \\
\hline 4725 Board packaging & 795 & 163 & 0.009 & 0.012 & 0.003 & 0.000 & 0.003 & 0.497 & 0.584 & 0.132 \\
\hline 4728 Other paper and boar & 127 & 148 & 0.011 & 0.029 & 0.018 & -0.004 & 0.003 & 0.786 & 0.758 & 0.150 \\
\hline 4751 Newspaper & 767 & 66 & 0.032 & 0.038 & 0.007 & 0.023 & 0.012 & 0.361 & 0.525 & 0.194 \\
\hline 4752 Periodicals & 1662 & 12 & 0.140 & 0.148 & 0.008 & 0.136 & 0.107 & 0.719 & 0.756 & 0.387 \\
\hline 4753 Books & 1350 & 22 & 0.090 & 0.099 & 0.009 & 0.084 & 0.062 & 0.660 & 0.766 & 0.405 \\
\hline 4754 O ther publishing & 8130 & 74 & 0.029 & 0.030 & 0.001 & 0.022 & 0.013 & 0.387 & 0.537 & 0.270 \\
\hline 4811 Rubber tyres & 38 & 188 & 0.006 & 0.093 & 0.087 & -0.010 & -0.011 & 0.936 & 0.929 & 0.211 \\
\hline 4812 O ther rubber & 530 & 179 & 0.007 & 0.014 & 0.007 & -0.002 & 0.001 & 0.596 & 0.617 & 0.106 \\
\hline 4820 Retreading & 44 & 88 & 0.020 & 0.054 & 0.034 & 0.005 & 0.017 & 0.919 & 0.858 & 0.159 \\
\hline 4831 Plastic coated texti & 19 & 21 & 0.094 & 0.227 & 0.133 & 0.100 & 0.102 & 0.960 & 0.960 & 0.368 \\
\hline 4832 Plastic semi-manufac & 418 & 189 & 0.006 & 0.015 & 0.009 & -0.004 & 0.008 & 0.709 & 0.623 & 0.096 \\
\hline 4833 Plastic floorcoverin & 29 & 208 & 0.001 & 0.100 & 0.099 & -0.016 & -0.009 & 0.949 & 0.939 & 0.241 \\
\hline
\end{tabular}




\begin{tabular}{|l|r|r|r|r|r|r|r|r|r|r|}
\hline 4-digit industry & $\begin{array}{r}\text { Number } \\
\text { of "fims" }\end{array}$ & $\begin{array}{c}\text { Rank } \\
\text { on } \alpha\end{array}$ & $\alpha$ & $F$ & $M$ & $\gamma_{M S}$ & $\gamma_{E G}$ & $L_{R}$ & $L_{A}$ & $C I$ \\
\hline 4834 Plastic building pro & 531 & 180 & 0.007 & 0.013 & 0.006 & -0.002 & 0.003 & 0.598 & 0.596 & 0.122 \\
\hline 4835 Plastic packaging & 631 & 159 & 0.010 & 0.015 & 0.005 & 0.000 & 0.008 & 0.628 & 0.626 & 0.108 \\
\hline 4836 Plastics other & 2123 & 172 & 0.008 & 0.010 & 0.002 & 0.000 & 0.003 & 0.375 & 0.474 & 0.146 \\
\hline 4910 Jewellery & 802 & 8 & 0.181 & 0.189 & 0.009 & 0.177 & 0.140 & 0.818 & 0.845 & 0.527 \\
\hline 4920 Musical instruments & 79 & 149 & 0.011 & 0.063 & 0.052 & -0.005 & -0.007 & 0.892 & 0.870 & 0.228 \\
\hline 4930 Photographic & 320 & 89 & 0.020 & 0.038 & 0.018 & 0.010 & 0.007 & 0.799 & 0.748 & 0.306 \\
\hline 4941 Toys and games & 246 & 181 & 0.007 & 0.037 & 0.030 & -0.005 & 0.005 & 0.820 & 0.780 & 0.134 \\
\hline 4942 Sports goods & 239 & 126 & 0.014 & 0.025 & 0.011 & 0.002 & 0.002 & 0.704 & 0.716 & 0.130 \\
\hline 4954 Misc. stationers go0 & 114 & 103 & 0.018 & 0.053 & 0.035 & 0.003 & 0.005 & 0.831 & 0.825 & 0.246 \\
\hline 4959 Other manufacturing & 2808 & 173 & 0.008 & 0.010 & 0.002 & 0.000 & 0.001 & 0.367 & 0.481 & 0.160 \\
\hline
\end{tabular}




\section{References}

Arrow, K (1962), "The economic implications of learning by doing" Review of E conomic Studies, $29,155-173$

Disney, R.., Haskel, J. and Heden, Y. (1999) "Entry, exit and survival in UK manufacturing" Q ueen Mary and Westfield College, draft paper.

Dumais, G., Ellison, G. and Glaeser, E. (1997) "Geographic concentration as a dynamic process", NBER working paper 6270.

Ellison, G. and Glaeser, E. (1997) "Geographic concentration in US manufacturing industries: a dartboard approach" Journal of Political E conomy, 105:5, 889-927

Glaeser, E, Kallal, H. Scheinkman, J. and Shleifer, A. (1992) "Growth in cities" Journal of Political E conomy, 100, 1126-1152.

Griffith, R. (1999) "Using the ARD establishment level data: an application to estimating production functions" E conomic Journal, 109, F416-F442.

Head, K., Ries, J. and Swenson, D. (1995) "Agglomeration benefits and location choice: evidence from Japanese manufacturing investments in the United States", Journal of International E conomics, 38, 223-247.

Henderson, J (1994) “Where does an industry locate?” Journal of U rban E conomics, 35, 83-104

Henderson, J (1995) "Industrial development in cities" Journal of Political E conomy, 103, 10671090

Hines, J.R. (1996) "Altered States: taxes and the location of foreign direct investment in America", A merican E conomic Review, 86, 1076-1094.

Hoover, E. (1936) L ocation Theory and the Shoe and L eather Industries, Harvard University Press: Cambridge MA

Jacobs (1969) The E conomics of Cities, Vintage: New Y ork

Jaffee, A.B., Traijtenberg, M. and Henderson, R. (1996) "Geographic localisation of knowledge spillovers as evidenced by patent citations", QJE.

Krugman, P.R. (1991a) "Increasing returns and economic geography" Journal of Political E conomy, 99, 483-499.

Krugman, P.R. (1991b) G eography and T rade, Cambridge, USA: MIT Press.

Krugman, P.R. (1994) Rethinking International Trade, Cambridge, USA: MIT Press.

Marshall, A (1890) Principles of E conomics, MacMillan: London

Maurel, F. and Sedillot, B. (1999) "A measure of the geographic concentration in French manufacturing industries", Regional Scienœ and U rban E conomics, 29(5), 575-604.

Oulton, N. (1997) "The ABI respondents database: a new resource for industrial economics research" E conomic T rends No. 528, November 1997,

Romer, P. (1990) "Increasing returns and long-run growth" Journal of Political E conomy, 94,1002-37. 
Swann, G.M.P., Prevezer, M. and Stout, D (1998) The dynamics of industrial dustering: international comparisons in computing and biotechnology, O xford University Press.

Venables, A. (1994) "Trade policy under imperfect competition: a numerical assessment" in Krugman, P. and Smith, A. (eds) E mpirical Studies of Strategic Trade Policy, Chicago: Chicago University Press. 